\title{
Terrane Processes at the Margins of Gondwana: introduction
}

\author{
Alan P.M. Vaughan ${ }^{1}$, Philip T. Leat ${ }^{1}$ \& Robert J. Pankhurst ${ }^{2}$ \\ ${ }^{1}$ British Antarctic Survey, High Cross, Madingley Road, Cambridge CB3 OET, U.K. \\ (e-mail:a.Vaughan@bas.ac.uk) \\ ${ }^{2}$ British Geological Survey, Keyworth, Nottingham NG12 5GG, U.K.
}

NB. The introduction should be aimed at the non-specialist geologist and about the $2^{\text {nd }}$ to $3^{\text {rd }}$ year undergraduate.

No of words in text: 6878

No of references: 260

No of tables: 0

No of Figures: 2

Running Title: Terrane Processes 
Abstract: The process of terrane accretion is vital to the understanding of the formation of continental crust. Accretionary orogens affect over half of the globe and have a distinctively different evolution to Wilson type orogens. It is increasingly evident that accretionary orogenesis has played a significant role in the formation of the continents. The Pacific-margin of Gondwana preserves a major orogenic belt, termed here the "Australides”, that was an active site of terrane accretion from Neoproterozoic to Late Mesozoic times, and comparable in scale to the Rockies from Mexico to Alaska, or the Variscan-Appalachian orogeny. The New Zealand sector of this orogenic belt was one of the birthplaces of terrane theory and the Australide orogeny overall continues to be an important testing ground for terrane studies. This volume summarizes the history and principles of terrane theory and presents sixteen new works that review and synthesize the current state of knowledge for the Gondwana margin, from Australia through New Zealand and Antarctica to South America, and examine the evolution of the whole Gondwana margin through time.

\section{Introduction}

Why this book? Two main types of orogenic belt have been identified on the Earth: orogens of the Wilson-type (e.g., Wilson 1966; Murphy \& Nance 2003), involving collision between continents, and orogens of the accretionary, Cordilleran type (e.g., Sengör \& Natalin 1996; Tagami \& Hasebe 1999; Scarrow et al. 2002), where a more steady state addition of smaller crustal fragments occurs. In simplest terms, collisional orogens are assumed to be the end-point of cycles of ocean formation and destruction during continental break-up and re-amalgamation (the so-called "Wilson Cycle”); accretionary orogens are the product of more continuous processes of 
addition of oceanic, island arc, and ocean-captured continental material to oceanic margins during long-term subduction, often without oceanic closure. Accretionary orogens are often characterized by being much wider across-strike than collisional orogens (Sengör \& Okurogullari 1991). Overall, it would seem that collisional and accretionary orogens form end members of a spectrum (Murphy \& Keppie 2003; Murphy \& Nance 2003). The Wilson-type end member is the “aulacogen” (e.g., Zolnai 1986; Pedrosa-Soares et al. 2001), where there is little or no displacement of continental margins and the ocean basin, which is often narrow, often closes up with jig-saw precision. The simplest accretionary end-member consists of a complex or prism (e.g., Leggett 1987; Doubleday et al. 1994; Kamp 2000), created through scraping-off of the upper parts of oceanic lithosphere as it is subducted. This may form at a continental margin or adjacent to an intra-oceanic arc, and ultimately may be displaced large distances, either across ocean basins or along continental margins, during, or subsequent to, formation. Real situations are a complex mix of Wilsonand accretionary types (e.g., Betts et al. 2002), where full-scale oceans that form with or without subsequent closure may have accretionary complexes on their margins, and experience subsidiary terrane and arc-collisional orogens that themselves incorporate accretionary complexes. Even "pure” accretionary orogens, such as the UralideAltaid orogen that forms much of Asia (Sengör \& Natalin 1996), where there is no evidence of continent-continent collision, consist of many minor terrane and arc collisional orogens that occurred on the margins of a long-lived ocean. The understanding of the relative significance of Wilson-type and accretionary orogens has changed with time. Historically, much early work focussed on Wilson-type orogenesis, particularly in the context of the circum-Atlantic orogens affecting northwest Europe and eastern North America from Proterozoic through to Late 
Palaeozoic times (e.g., Phillips et al. 1976; Williams \& Hatcher 1982; Keppie 1985a; Ryan \& Dewey 1997; Matte 2001; Young et al. 2001; Bandres et al. 2002; Gower \& Krogh 2002), which may have inflated its significance in global terms. Williams \& Hatcher (1982) were the first to show that a Wilson-type model may not be appropriate for the case examples associated with the evolution of the Iapetus Ocean and this is supported by more recent lithostratigraphic, faunal and palaeomagnetic data (O'Brien et al. 1983; Cocks \& Torsvik 2002; Hartz \& Torsvik 2002). Doubts about its applicability to the Pacific Cordillera of western North America came even earlier (Danner 1970). Although major, Wilson-type continental collision can form long lived continents such as Gondwana (e.g., Unrug 1992; Boger et al. 2001), global syntheses (e.g., Sengör \& Natalin 1996) have emphasized the importance of accretionary orogens, arguing that these were responsible for growth and stabilization of millions of $\mathrm{km}^{2}$ of the continental lithosphere from Archaean times onwards (Sengör et al. 1993; Foster \& Gray 2000; Polat \& Kerrich 2001; Xiao et al. 2004). Accretionary orogens are directly and indirectly host to globally important mineral deposits (e.g., Richards \& Kerrich 1993; Sherlock et al. 1999; Kerrich et al. 2000; Goldfarb et al. 2001). For example, volcanic arc and back-arc terranes form an important part of accretionary orogens and it is increasingly recognized that active, submerged arcs and back-arcs are sites of significant metallogenesis (e.g., Fouquet et al. 1991; Ishibashi \& Urabe 1995; Iizasa et al. 1999; Fiske et al. 2001). Submarine arc-hosted mineral deposits are not easily accessible in their sites of formation because sea-floor mining is technically challenging (e.g., Scott 2001); however, terrane accretionary orogenesis has an additional importance in incorporating arc and sea-floor mineral deposits in continental lithosphere, making them accessible to simpler extraction techniques. Finally, in this volume, Vaughan \& Livermore 
(2005) present evidence that accretionary orogenesis is not uniformly distributed in time, with implications for our understanding of Earth evolution. Vaughan \& Livermore (2005) show that two major pulses of terrane accretion occurred in the Mesozoic, not just affecting the "Australides" on the Gondwana margin but with global extent, possibly associated with major episodes of flood magmatism.

The accretionary orogenic belt that formed on the palaeo-Pacific and Pacific margin of Gondwana in Neoproterozoic-Mesozoic times (Fig. 1) (Ireland et al. 1998) is one of the largest known orogenic belts in Earth history. The orogen (the Neoproterozoic to Palaeozoic part of this orogeny has been called the Terra Australis orogen by Cawood \& Leitch (2002)) now occupies the eastern third of Australia, New Zealand, West Antarctica, the Transantarctic Mountains and large parts of southern South America (Fig. 1) (e.g., Bradshaw 1994; Cawood \& Leitch 2002). Several factors have hampered reconstruction of this Neoproterozoic to Mesozoic orogenic belt - a timeextended Terra Australis orogen, finishing in the mid-Cretaceous, which we will informally refer to here as the "Australides"; Fig. 1. These include dismemberment and dispersal of its components during Mesozoic break-up of the supercontinent Gondwana, burial of large parts of it beneath ice (in Antarctica) and later sedimentary basins (in all other parts of the belt), local submergence of continental margins (notably the continental margins of New Zealand), and partial obliteration and overprinting by continued subduction-related magmatism and deformation (as in many parts if the Andes and Antarctic Peninsula). The size of the reconstructed orogenic belt - over $7000 \mathrm{~km}$ long by over $1500 \mathrm{~km}$ wide - is larger than the Mesozoic-Cenozoic orogenic belt that extends from Alaska to Mexico along the 
Pacific margin of the North American continent and is comparable in scale to the Variscan orogenic belt of Europe and eastern North America (Matte 2001).

The better-understood western North American orogenic belt or "Cordillera" (Fig. 1) was the first to be interpreted as a collage of 'suspect' terranes (as summarized by Coney et al. 1980) - terranes being fault-bounded blocks of the Earth’s crust characterized by a geological history distinct from that of adjacent terranes. This model has been widely and successfully applied to many ancient orogenic belts. One important aspect of the model is that some of the terranes in a collage may have travelled great distances from their places of origin to their final location adjacent to other terranes or the continental margin. This may have occurred either across oceans or along a continental margin by transcurrent faulting (e.g., Keppie \& Dallmeyer 1987; Mankinen et al. 1996; Cowan et al. 1997; Takemura et al. 2002). The terrane model was applied early in its inception to parts of the Pacific margin of Gondwana (Coombs et al. 1976; Bradshaw et al. 1981; Weaver et al. 1984; Murray et al. 1987). It is now almost universally accepted that terrane-style tectonics are of major importance in the development of orogenic belts.

Understanding of the “Australide” orogen (Fig. 1) and the role of terrane processes in its development has progressed rapidly during the last decade. There are several reasons for this:

1. There has been increasing realization that problems of tectonic correlation within the orogen are best solved by comparisons between the now-dispersed parts of the belt. Increasing knowledge of formerly less-well known parts of 
the orogen and greater international co-operation in sharing such knowledge (notably through UNESCO-funded International Geological Correlation Programmes, such as IGCP 436 “Pacific Gondwana Margin”) have been important. The formerly adjacent parts of the orogen may have been either sediment sources or terrane sources (e.g., Adams et al. 1998; Cawood et al. 2002).

2. The advent of routine, accurate and precise $\mathrm{U} / \mathrm{Pb}$ dating of zircons has led to more refined correlation of events and provided information on the provenance of the huge piles of quartz-bearing sediments that characterize much of the orogen (e.g., Ireland et al. 1998; Fergusson \& Fanning 2002; Hervé et al. 2003; Schwartz \& Gromet 2004; Wandres et al. 2004). Advances in the routine application of ${ }^{40} \mathrm{Ar} /{ }^{39} \mathrm{Ar}$ dating have also been beneficial to provenance studies as well as the dating of deformation events (Adams \& Kelley 1998; Vaughan et al. 2002).

3. Improved geochemical analytical methods for analysing trace and rare earth elements in volcanic rocks (especially ICP-MS), and greater understanding of their compositional variations has lead to growing confidence in assigning tectonic settings to the volcanic arcs that are key elements in the orogenic belt for palaeotectonic reconstructions (e.g., Glen et al. 1998; Spandler et al. 2004; Wang et al. 2004).

4. Increased use of remote sensing techniques and improved regional compilations of data, especially magnetic potential field, has been highly effective in mapping and characterizing terrane boundaries, especially when submerged or covered by surficial deposits or ice (e.g., Ferraccioli \& Bozzo 1999; Sutherland 1999; Direen \& Crawford 2003). 
5. Palaeontological discoveries and better biostratigraphical correlation have been important in the recognition that terrane activity continued into the Mesozoic and have provided qualitative estimates of terrane transport directions and distances (Benedetto 1998; Fang et al. 1998; Kelly et al. 2001; Cawood et al. 2002).

This book is the first to provide an overview of understanding of the terrane model as it applies to the Australide accretionary orogeny on the Pacific margin of Gondwana. It reviews the work of research groups from North and South America, Europe and Oceania who are engaged in active research on the nature of the Gondwana margin and the accretionary orogeny (Regions covered by chapters of this book are indicated on Figure 2.). This volume offers a snapshot of current thinking and current research directions, and a guide for any researcher currently active or about to embark on studies in this dynamic area of investigation. We judge that now is the correct time to summarize recent progress, and highlight the scientific questions that are currently engaging those active in the field and that will drive future research.

\section{Nomenclature}

According to Coney et al. (1980), terranes 'are characterized by internal homogeneity and continuity of stratigraphy, tectonic style and history’. They stated that 'boundaries between terranes are fundamental discontinuities in stratigraphy that cannot be explained easily by conventional facies changes or unconformity'. The fundamental features of terranes are therefore that (a) their boundaries are major faults, and (b) they have different geological histories to adjacent terranes. These 
features are summarized in our preferred definition of terranes as ' $a$ fault-bounded package of rocks of regional extent characterized by a geologic history that differs from that of neighbouring terranes' (Howell et al. 1985; Friend et al. 1988). Recognition of terranes is not based on any inferences about distance travelled or relative movement between adjacent terranes (Parfenov et al. 2000). Terranes are 'suspect' if there is doubt about their palaeographical setting with respect to adjacent terranes or continental margins (Coney et al. 1980; Coombs 1997). Terranes may be described as 'exotic', 'far-travelled' or allochthonous’ (all meaning about the same thing) if there is sufficient evidence that they originated far from their present locations, often assumed to be hundreds or thousands of kilometres away; however, these distances need not be particularly large in areas of complex geology (Coombs 1997). Problems of definition have been discussed in the literature (e.g., Sengör \& Dewey 1991), mainly from perspectives of recursion, i.e., is a seamount in an accretionary complex a separate terrane or just part of the complex, and problems of lateral and/or vertical extent, i.e., how small, or large, can a terrane be (Sengör 1990).

\section{Development of the terrane concept}

Recognition that fragments of continental margins had moved long distances came, in the late 1940’s and early 1950’s, from the discovery that transcurrent faults had hundreds of kilometres of offset (Kennedy 1946; Hill \& Dibblee 1953; Wellman 1955). Coombs (1997), in a brief review of the terrane concept, pointed out that the term "terrane” was in use as early as the 1920's and 1930's, but that modern usage stemmed from the work of Irwin $(1964 ; 1972)$ in the western Cordillera of the United States. Following further conceptual development in the 1970’s in western North 
America and New Zealand (Berg et al. 1972; Monger et al. 1972; Blake et al. 1974;

Coney 1978; Howell 1980), the concept of terranes, or terrane collages, as possibly far-travelled, fault-bounded blocks with geological histories different from that of adjacent blocks, was crystallized by Coney et al. (1980). The model was quickly tested in other orogens (e.g., Bradshaw et al. 1981; Williams \& Hatcher 1982; Ziegler 1982; Pigram \& Davies 1987), and large numbers of 'suspect' terranes were identified in most. In the case of the lower Palaeozoic Caledonian-Appalachian orogen in Scandinavia, the British Isles and eastern USA and Canada, terranes were sandwiched between continents on opposing sides of the closing Iapetus Ocean (Williams \& Hatcher 1982; Hutton 1987; Pickering et al. 1988; Rankin et al. 1988; Hibbard 2000; Roberts 2003). This orogen, therefore, had a phase of accretionary tectonics prior to continent-continent collision. As outlined above, studies of the margin of the Pacific basin were instrumental in the creation of the terrane concept and have provided the impetus for its continued development. In the past ten years, the fundamental importance of terrane processes in generating and stabilizing continental lithosphere has become apparent from studies of the Altaid belts of Asia (Sengör et al. 1993; Sengör \& Natalin 1996) and the orogens that comprise eastern Australia (Foster \& Gray 2000) - a system comprehensively reviewed by Glen (2005) in this volume. Application of these ideas to older rocks indicates that terrane amalgamation and accretionary orogenesis may be the most important processes in formation of the continental lithosphere through time (Polat \& Kerrich 2001).

\section{Terrane processes}


The key processes of terrane formation are accretion and dispersal. Accretion (or "docking" (Twiss \& Moores 1992)) is the process by which material incorporated in, or transported by, oceanic plates is added to subducting margins, usually separated from the adjacent, over-riding oceanic or continental plate by a narrow zone called a suture (Howell 1989). Sutures may be marked by belts of ophiolitic (e.g., Johnson et al. 2003) or high pressure rocks, such as blueschists (e.g., Kapp et al. 2003), but survival of these rocks is not essential to the definition and sutures may also be represented by strike-slip faults, thrusts or zones of mélange (e.g., Abdelsalam et al. 2003; Pavlis et al. 2004). Suture zones are not exclusive to accretionary orogens (e.g., Vaughan \& Johnston 1992). Dispersal is the process by which fragments are detached or redistributed from the overriding plate at active margins during subduction or ridge crest-trench collision (e.g., Nelson et al. 1994; Keppie et al. 2003) by rifting (e.g., Umhoefer \& Dorsey 1997), strike-slip faulting (e.g., Cawood et al. 2002) or thrusting (e.g., Fritz 1996). Both accretion and dispersal result in new terranes, either by adding previously separate geological entities such as oceanic plateaus or sea-mounts to oceanic margins, or by removing pieces of existing margins and transporting them elsewhere. The third main process is amalgamation (e.g., Bluck 1990), by which existing terranes are combined into larger, composite terrane collages or superterranes, ultimately forming stable parts of the continental lithosphere. Examination of Cenozoic to Recent active accretionary orogens in southeast Asia suggests that the interaction between accretion, dispersal and amalgamation can be extremely complex with geologically very rapid changes that may not be recognized in older orogens without high resolution dating (Hall 2002). Other important terrane processes happen after accretion, dispersal or amalgamation. These are the formation of sedimentary or volcanic overlap sequences and 
emplacement of igneous complexes that "stitch" terrane sutures and place time limits on terrane motion (e.g., Gardner et al. 1988; Raeside \& Barr 1990; Herzig \& Sharp 1992).

\section{Types of terrane}

The common terrane rock types tend to be similar from orogen to orogen and we have grouped these into several main associations. The most common types in Phanerozoic orogens around the world are marginal to the ocean basins and can encompass any type of continental or oceanic lithosphere, either with or without a mantle root. Most common, non-genetic (i.e. what a geologist would see at outcrop in the field) where possible, terrane rock type associations, based on the Australides (this book and references therein) western American Cordillera, Caledonian-Appalachian, central and eastern Asia orogens (Coney et al. 1980; Williams \& Hatcher 1982; Hutton 1987; Parfenov et al. 2000; Badarch et al. 2002; Xiao et al. 2004), are:

1. Turbidite terranes. These are volumetrically very significant, forming large parts of the accretionary orogens in New Zealand (e.g., Leverenz \& Ballance 2001; Mortimer 2004), Australia (e.g., Foster \& Gray 2000), eastern Asia (e.g., Sengör \& Okurogullari 1991), the western North American Cordillera (e.g., Rubin \& Saleeby 1991; McClelland et al. 1992) and in Palaeozoic orogens of northwest Europe and eastern North America (e.g., Keppie 1985b; Leggett 1987; Lehmann et al. 1995; Ryan \& Smith 1998). They comprise thick piles of deep marine sediments, probably representing submarine fans, and are often imbricated by thrusting (e.g., Kusky \& Bradley 1999). They are 
commonly siliciclastic, particularly in the Southern Hemisphere (e.g., Adams et al. 1998; Ireland et al. 1998), but substantial calcareous complexes also exist (e.g., Robertson \& Ustaomer 2004; Wilson et al. 2004). Parfenov et al. (2000) subdivided these terranes into three types: two accretionary complex types with greater or lesser proportions of basaltic rocks, and a nonaccretionary type where the evolutionary history of the turbidite succession is less certain (e.g., possibly dispersed from a passive continental margin but with no subsequent incorporation in a subduction complex). Turbidite terranes are commonly metamorphosed (e.g., Hervé \& Fanning 2001), from anchimetamorphic up to blueschist and amphibolite grade, and associated brittle-ductile and ductile deformation is common (e.g., Wang \& Lu 1997; Willner et al. 2004).

2. Tectonic and sedimentary mélange terranes. These are commonly associated with turbidite terranes, particularly those generated in a subduction environment (e.g., Ernst 1993; Kusky \& Bradley 1999), and often occur along terrane sutures (e.g., Aitchison et al. 2002) or at major boundaries within accretionary complex terranes (e.g., Silberling et al. 1988). They commonly consist of altered basalt and serpentinite, chert, limestone, greywacke, shale, and metamorphic rock fragments (including blueschist) in a fine-grained sheared and cleaved mudstone matrix (e.g., Aalto 1981; Cloos 1983; Carayon et al. 1984; Maekawa et al. 2004).

3. Magmatic terranes. These can be predominantly mafic or predominantly felsic, reflecting the geological environment in which they formed. Mafic 
magmatic terranes are dominated by volcanic and plutonic rocks, usually pillow basalts associated with volcanogenic and pelagic sediments (e.g., Takemura et al. 2002), subaerial flood basalts (e.g., Richards et al. 1991), sheeted dyke complexes (e.g., Lapierre et al. 2003), and mid-lower crustal lithologies dominated by mafic and ultramafic plutonic complexes (e.g., DeBari \& Sleep 1991; Shervais et al. 2004). In some cases, related ultramafic rocks in mafic magmatic terranes may be of mantle origin (Fitzherbert et al. 2004). Most mafic magmatic terranes are interpreted to have been generated by either sea-floor spreading, oceanic intraplate magmatism, or in volcanic arc environments, although terranes derived from dispersal of continental flood basalt magmatic rocks are also known (e.g., Song et al. 2004). The products of sea-floor spreading include ophiolites and other fragments of oceanic basement that were commonly produced in back-arc settings (e.g., Bluck et al. 1980; Cawood \& Suhr 1992; Bédard 1999; Yumul 2003; Piercey et al. 2004). Terranes derived from sea-floor volcanic eruptions include oceanic plateaus formed by oceanic flood eruptions (e.g., Wrangellia terrane, Richards et al. 1991; Hikurangi Plateau, Mortimer \& Parkinson 1996), as well as seamounts and ocean islands (e.g., Jacobi \& Wasowski 1985; Barker et al. 1988; Doubleday et al. 1994). Mafic magmatic terranes are commonly intra-oceanic and formed on oceanic rather than continental crust (e.g., Weaver et al. 1984; DeBari \& Sleep 1991; Rubin \& Saleeby 1991; Miller \& Christensen 1994). Dominantly felsic magmatic terranes mostly consist of broadly calc-alkaline, plutonic rocks that represent the interiors of volcanic arcs, although some may represent dispersed fragments of older felsic continental crust, possibly cratonderived, reincorporated in later orogens (e.g., Boger et al. 2001). In addition 
to rocks of the calc-alkaline suite, a common association in felsic magmatic terranes is the tonalite-trondhjemite-granodiorite suite (e.g., Smithies 2000). The Phanerozoic equivalents of these rocks are called adakites and their origin is controversial (e.g., Defant et al. 2002; Kay \& Kay 2002). They are thought to be generated by high heat flow in several subduction-related settings where partial melting took place in the garnet stability zone, $>\sim 40 \mathrm{~km}$ depth, with end member models implicating either young subducting slab or partial melting of mafic lower arc crust (e.g., Defant et al. 2002; Kay \& Kay 2002). Terranes with rocks of this suite are typified by the 'Median batholith' and central magmatic arcs of South Island, New Zealand (Muir et al. 1998; Mortimer et al. 1999). Similar plutonic rocks are interpreted, from seismic evidence, to characterize some modern oceanic arcs (e.g., Suyehiro et al. 1996). Some felsic magmatic terranes, or at least some sequences within them, are dominated by felsic volcanic rocks at exposure level (e.g., Clift \& Ryan 1994; MacDonald et al. 1996; Bryan et al. 2001), which are interpreted to be the erupted equivalents of arc and back-arc pluton, although dispersed terranes derived from continental rhyolite large igneous province magmatism are known (e.g., Heatherington \& Mueller 2003).

4. Non-turbidite clastic, carbonate or evaporite sedimentary terranes. These terranes fall into two categories: well-bedded, shallow marine, fluvial, or terrestrial sequences, probably representing platform, rift margin, or shallow basin deposition, and a category consisting of massive limestones. Wellbedded terrane sequences often represent dispersed fragments of continental margin rocks, including clastic and volcaniclastic sediments (e.g., Campbell et 
al. 2001; Noda et al. 2004), carbonates (e.g., Gaetani et al. 2004) and evaporites (e.g., Thomas et al. 2001), but can also be deposits from arc-related basins (e.g., fore-arc Nichols \& Cantrill 2002) or aulacogens (failed rifts) (e.g., Zolnai 1986). Massive limestones are often masses scraped off seamount summits in accretionary complexes (e.g., Kimura et al. 1994; Stevens et al. 1997; Cawood et al. 2002).

5. Terrane collages. These consist of composite terranes formed by amalgamation of some or all of the above terrane types (e.g., the Argentine Precordillera (Thomas et al. 2002) and Avalonia (Nance et al. 2004)), with the added complication of internal sutures as well as internal overlap and stitch assemblages.

\section{Size of terranes}

This is a difficult subject. As with many natural objects, it is easier to know what something is than it is to define it. Parfenov et al. (2000) placed a lower size limit on terranes by defining them as units that can be mapped at the 1:5,000,000 scale, although they admitted that size limits are largely arbitrary. Sengör (1990) argued that nappes and blocks in mélange units should not be considered terranes, but more recent work would suggest that there is no effective lower size limit (mélange zones, for example, can be argued to consist of an arbitrarily large number of faults (e.g., Chang et al. 2001) - any exotic block in a mélange zone is, therefore, fault bounded and could be considered a terrane, although this is an extreme case). Composite terranes can be very large (e.g., modern New Zealand could be considered a 
composite terrane), and although composite terranes should be smaller than continents, there is no arbitrary upper limit to terrane size.

\section{Current research themes}

The study of tectonic plates in terms of terranes is called "terrane analysis" (e.g., Howell \& Howell 1995). Once a terrane has been recognized, by identification of its bounding faults, the next component of terrane analysis is characterization (e.g., Samson et al. 1990; Lapierre et al. 1992), which uses standard geological techniques such as mapping, geophysics (e.g., Brown 1991; Ferraccioli et al. 2002; Armadillo et al. 2004), sample collection and follow-up laboratory work etc. It is then necessary to determine the relationship between the terrane and the adjacent continental margin and other neighbouring terranes (e.g., Samson et al. 1991); this is often in combination with efforts to characterize a terrane. In most cases, especially in Palaeozoic orogens, it is easy to designate a terrane as 'suspect', but difficult to prove that it is exotic to the continental margin and its immediately adjacent marginal seas. Several techniques exist for testing the origin of a terrane (Howell \& Howell 1995). Where a terrane is suspect, techniques to determine qualitative or semi-quantitative estimates of absolute movement include palaeontology (e.g., Smith et al. 2001;

Belasky et al. 2002; Cawood et al. 2002; Kottachchi et al. 2002), palaeomagnetism (e.g., Johnston 2001; Keppie \& Dostal 2001) and palaeoenvironmental studies (e.g., Condie \& Chomiak 1996; Monger 1997; Trop et al. 2002). Some techniques do not give movement information directly, but can determine what relationship a terrane has to adjacent terranes and/or determine its ultimate origin. These include petrology (e.g., Barr 1990; Restrepopace 1992), isotope geochemistry (e.g., Samson et al. 1990; 
Leat et al. 2005), geochronology (e.g., Herrmann et al. 1994; Weber \& Kohler 1999), provenance studies of sandstones (e.g., Ireland et al. 1998; Friedl et al. 2000; Adams et al. 2002; Adams et al. 2005) and conglomerates (Wandres \& Bradshaw 2005, this volume), and sediment geochemistry (e.g., Willan 2003). Of the provenance techniques $\mathrm{U}-\mathrm{Pb}$ and $\mathrm{Hf}$ isotope dating and fingerprinting of zircon are particularly important because, in addition to age, they provide information about evolution of the crustal sources (Bodet \& Schärer 2000; Friedl et al. 2000; Knudsen et al. 2001; Griffin et al. 2004). A second approach to characterizing terranes and identifying their origins comes from comparison with modern analogues. For example, the Japan-Izu Bonin arc collision (e.g., Kawate \& Arima 1998; Soh et al. 1998) is a modern active example of accretion of a primitive magmatic arc to a composite microcontinental arc terrane. Taiwan preserves an active arc-continent collision zone between the Eurasian plate and the Philippine Sea plate (e.g., Fuh et al. 1997; Chang et al. 2001). The situation in Southeast Asia is complex and shows evidence for very rapid changes in plate boundaries on geological timescales, commonly coeval compressional and extensional regimes and abundant strike-slip (Hall 2002). Pigram \& Davies identified as many as 48 Cenozoic terranes in Papua New Guinea/Irian Jaya and the region shows a long history of terrane processes (Metcalfe 1994). The arccontinent collision between Australia and Indonesia/Papua New Guinea (e.g., Abbott et al. 1994), which is complicated by Pacific Plate interactions (e.g., Hall 2002), shows features of terrane dispersal even as terrane accretion is underway (e.g., Milsom et al. 1999), and includes an active collision zone between a submarine plateau (Ontong-Java) and the Melanesian arc (e.g., Hall 2002). Many of the features that developed during the Cenozoic development of the region of Southeast Asia and the southwest Pacific are at odds with interpretations of older accretionary orogens 
(R. Hall personal communication 2004) and the reasons for this mismatch are so far unexplained. The Lesser Antilles, by showing a system where sediments derived from a primitive arc mix with sediments that are cratonically derived, provide a modern analogue that illustrates the potential complexities of provenance analysis based on sediments (e.g., Marsaglia \& Ingersoll 1992; Faugeres et al. 1993; Leitch et al. 2003). Aerogeophysical techniques provide powerful tools for identifying terrane extents and boundaries in areas of ice (e.g., Ferraccioli et al. 2002) or thick sediment cover (e.g., Chernicoff \& Zappettini 2003). Another approach in characterizing and sourcing terranes is to determine the composition and gross structure of the terrane deep-lithosphere. This can be done by examining the compositions of deeply sourced magmas such as primitive mafic dykes and the compositions of any xenoliths they may have carried from depth (e.g., Yu et al. 2003; Leat et al. 2005, this volume), or by quantifying the structure of the lithosphere using energy from distant seismic sources such as earthquakes (e.g., Reading et al. 2003; Reading 2005, this volume) or magnetotellurics (e.g., Ledo et al. 2004).

\section{Terrane studies on the margin of Gondwana}

New Zealand

New Zealand was one of the places where the terrane concept was developed (Blake et al. 1974; Coombs et al. 1976; Howell 1980; Coombs 1997) and one of the first parts of the Gondwana margin where the terrane concept of Coney et al. (1980) was applied (Bradshaw et al. 1981). The terrane model has proved highly successful in understanding the pre-Late Cretaceous evolution of the region. It has been well tested 
(Bradshaw 1989; Adams \& Kelley 1998; Cawood et al. 1999; Sivell \& McCulloch 2000; Mortimer \& Cooper 2004), and there have been no competing models for the last twenty years. Early Palaeozoic terranes form a Western Province of Gondwana affinity, which is separated from late Palaeozoic to Mesozoic accreted terranes of an Eastern Province by a Median Tectonic Zone or batholith (Mortimer et al. 1999) that consists of late Palaeozoic to Mesozoic igneous rocks. The first-accreted Eastern Province terranes include ultramafic rocks (such as the type dunites of Dun Mountain: Coombs et al. 1976). Wandres \& Bradshaw (2005, this volume) review New Zealand's terranes and present new data on their origins using provenance of clasts in conglomerate deposits, arguing that the Antarctic Sector of the Gondwana margin is a major source of detritus. Similarly, Adams et al. (2005, this volume), use Sr and $\mathrm{Nd}$ isotopes of metasedimentary sequences in the "Australides" from Australia to southern South America to characterize Gondwana margin accretionary complexes and the nature of their sources. A simple conclusion of this work is that at any one time material of different origins was being deposited and accreted in different parts of the orogen, and that the accretion history of West Antarctica and southern South America is distinct from that of New Zealand.

\section{Australia}

The Tasman orogenic system 'Tasmanides' of Australia occupies the eastern third of the Australian continent. It consists of several orogenic belts whose age of deformation and accretion decreases from west to east (Murray et al. 1987; Coney et al. 1990; Flöttmann et al. 1993; Glen et al. 1998; Ireland et al. 1998; Fergusson 2003; McElhinny et al. 2003). The Early Palaeozoic Delamerian orogeny formed as 
Neoproterozoic and Cambrian sedimentary and volcanic arc terranes were accreted along the formerly passive margin of the western Australian Precambrian continental core. This orogen an along-strike correlative of the Ross orogeny in Antarctica (Stump et al. 1986; Flöttmann et al. 1993). To the east, the Early Palaeozoic Lachlan and Thomson fold belts represent accretion of Cambrian to Silurian volcanic arcs and dominantly siliciclastic sediments to the margin (e.g., McElhinny et al. 2003). The eastern New England orogeny represents accretion of terranes during late Palaeozoic to early Mesozoic times. In this volume, Glen (2005) comprehensively reviews current models for the development of the Tasman orogenic system and identifies three supercycles of sedimentation and deformation. His proposed model is one of essentially continuous accretionary orogeny at the Pacific margin of eastern Australia since Neoproterozoic times. The deep structure of terranes is also important.

Reading (2005, this volume) presents a new technique for imaging the deep roots of southwestern and southeastern Australian terranes and terranes boundaries using earthquake seismic data.

\section{South America}

The first ideas that the South American margin might consist of accreted terranes was presented in relation to a Permian carbonate fragment in southern Chile known as the Madre de Dios terrane (Mpodozis \& Forsythe 1983). Subsequent work on most of the meta-sedimentary rocks of the southernmost Pacific Andean margin has shown that they do not represent Palaeozoic Gondwana basement as once supposed, but are best interpreted as Mesozoic accreted material (Hervé 1988; Fang et al. 1998; Hervé \& Fanning 2003). East of the Andes, the Argentine Precordillera is widely regarded as a 
large-scale exotic terrane derived from Laurentia and accreted during the Early Palaeozoic (e.g., Ramos et al. 1986; Moore 1994; Astini et al. 1995; Thomas \& Astini 2003). Much research has been focused on refining models for the history of this Precordillera or Cuyania terrane. Nevertheless, others have disputed its Laurentian derivation, preferring an autochthonous origin within Gondwana (Aceñolaza et al. 2002). It is notable that geochronology and detrital zircon analysis have been central to the development of both sides of this controversy (Casquet et al. 2001; Thomas et al. 2004; Finney et al. in press). In any event, it is becoming increasingly obvious that western South America retains a fragmentary record of high-grade Proterozoic metamorphic rocks coeval with the Grenville belt of North America (e.g., Thomas et al. 2004). Cordani et al. (2005, this volume) present new evidence for Proterozoic, Grenvillian fragments in the Columbian Andes, and Casquet et al. (in press) have identified Grenville-age massif anorthosites in western Argentina, comparable to those of the Grenville province. This 'southern Grenville belt' may well represent a common orogeny linking Laurentia and 'Western Gondwana’ within Rodinia.

Another aspect of importance in terrane accretion is the tectonic history of the collision zone. Miller \& Söllner (2005, this volume) present evidence that the Famatina Complex represents autochthonous arc-continent collision on the Gondwana margin in Late Proterozoic to Ordovician times, which could be related to accretion of the Precordillera terrane. Zimmermann (2005, this volume) uses new provenance data from Late Proterozoic to Cambrian sediments of the Puncoviscana basin to show that the rocks represent a peripheral foreland basin succession to the Pampean orogeny. As a counterpoint to terrane interpretations of southern South America, Lucassen \& Franz (2005, this volume) present an alternative history for the 
early Palaeozoic of the Central Andes proposing a non-terrane, tectonic situation similar to the present day.

Attempts to view the rest of South America in terrane terms were advanced by Bernasconi (1987) for the Precambrian and Ramos (1988) for the Phanerozoic. The current stage is one where the identification and characterization of terranes in poorly exposed or poorly studied areas, which potentially include Patagonia, has not been convincingly demonstrated. Geophysical evidence is crucial in such in such circumstances (e.g., Chernicoff \& Zappettini 2003). Rapalini (2005, this volume) reviews southern South American terranes from east to west, and provides new insights into key events during Gondwana assembly in the Neoproterozoic to Late Palaeozoic from the perspective of palaeomagnetic data. Rapela et al. (2005, this volume) identify a previously unknown Early Jurassic magmatic arc and show that magmatism in the Triassic-Jurassic interval reveal a rotational tectonic regime which should be a major constraint on the plate configuration of Patagonia and the relationship between southern South America and the Antarctic Peninsula in prebreak-up Gondwana reconstructions.

\section{Antarctica}

The ice cover of most of both East and West Antarctica has hampered regional correlations. Nevertheless, it is becoming increasingly clear that most of East Antarctica consists of a collage of Archaean blocks and Proterozoic belts that were finally stabilized in their current configuration during the Pan-African orogeny ( $c$. 700-500 Ma) when the Mozambique Ocean separating East and West Gondwana closed to form the Gondwana continent (Fitzsimons 2000a, b; Boger et al. 2002; 
Jacobs et al. 2003). Closure of this ocean around the end of Precambrian times formed the continuous Pacific margin of the Gondwana continent along which the Palaeozoic to Mesozoic orogenic belts developed (Fig. 1). During the Mesozoic break-up of Gondwana, West Antarctica behaved as several crustal blocks separated by rift and strike-slip deformation zones (Dalziel \& Elliot 1982). Stone \& Thomson (2005, this volume) present fossil evidence that supports rotation of the Falklands microplate during Gondwana break-up and has implications for the extent of the Gondwanide ice sheet. Siddoway et al. (2005, this volume) show new evidence for strike-slip movements affecting West Antarctica during the Cretaceous just prior to the rifting-off from Gondwana of New Zealand (Laird \& Bradshaw 2004). West Antarctica appears to mostly consist of crust accreted to the Antarctic margin during Cambrian to Cretaceous times. Terranes were first identified in the Ross orogeny of the Transantarctic Mountains where Cambrian sedimentary and volcanic arc terranes were accreted to the margin in Cambrian times (Weaver et al. 1984; Stump 1995). The extent to which these terranes are exotic to the Gondwana margin is a matter of current debate and Tessensohn \& Henjes-Kunst (2005, this volume) present a review of the most recent results and models.

West Antarctica appears to consist of Early Palaeozoic to Mesozoic provinces, at least some of which are "suspect" (e.g., Pankhurst et al. 1998; Vaughan \& Storey 2000; Millar et al. 2002). Rocks of Proterozoic age (1176 \pm 76 Ma, Millar \& Pankhurst 1987) crop out in just one location in West Antarctica, at Haag Nunataks. There is continuing uncertainty whether this is an isolated far-travelled terrane derived from a continental margin, a fragment of the Gondwana core or whether it represents more extensive Proterozoic basement to West Antarctica, as indicated by 
isotope studies of granites and xenoliths (Millar et al. 2001; Handler et al. 2003).

Leat et al. (2005) shed some light on this by using lithosphere-derived mafic magmas to determine differences in lithospheric mantle composition beneath Antarctica.

\section{Other parts of the Gondwana margin}

Studies of the interaction between Gondwana and Laurentia have been an important driver of orogenic theory. When Wilson (1966) asked if the Atlantic had closed and then reopened, the closure he referred to was between Gondwana and Laurentia. Williams \& Hatcher (1982; 1983) demonstrated that this closure had incorporated many exotic terranes in one of the first demonstrations of the utility of the terrane collage model of Coney et al. (1980). Hibbard et al. (2005, this volume) present a re-examination of the Gondwana-Laurentia terrane-collision orogeny in the Carolina Zone of the Appalachian belt and present a new model for middle Palaeozoic interactions of the Appalachian peri-Gondwanan realm with Laurentia.

\section{Some suggestions for the future}

Geological mapping, augmented by geochronology, geochemistry, palaeontology, and aerogeophysical methods, continues to be the foundation stone of terrane analysis. New techniques such as 1-D seismic analysis, Hf-isotope investigation of zircon, and xenolith studies promise to provide further new insights into terrane deep structure and provenance. Geophysical studies, integrated with geological field data, are allowing us to better predict what lies beneath the ice of Antarctica. Despite the many recent advances, there are still some significant gaps in our knowledge. 1-D seismic 
studies would benefit from increased Antarctic coverage of permanent seismic data recorders, which is low relative to other continents. Hf-isotope studies are currently hampered by incomplete sets of representative Hf data from potential source rocks for Gondwana terranes. In a sense we need to know the "Hf of the world" to give us more confidence in our interpretation of Gondwana provenance data and, to this end, we recommend that all zircon mounts that have been dated by the U-Pb SHRIMP method are analysed in-situ for Hf. In regional terms, linking the Australia-New Zealand sector of the Australides with the South American sector is made more difficult by a gap in geological and high-resolution aerogeophysical data in the Pine Island Bay area of Ellsworth Land. This area is currently a target of glaciological research, but it needs to be made a key target for geology and aerogeophysics. It is clear that the long period of Phanerozoic subduction beneath this margin had a large impact on mantle evolution of the southern hemisphere. However, there is a need for more robust regional models - building on excellent local data sets - for the origin and relationship of the diverse mantle reservoirs that have sourced magmatism in the Australides. A deeper understanding of terrane processes is likely to result from closer comparisons between the Australides and the Cenozoic accretionary orogens of Southeast Asia, and the southwest Pacific, by re-assessing data and interpretations of older orogens in the context of the well-constrained processes and events described from Cenozoic margins. In simple terms, we should look for analogues of Mesozoic, and older, processes in younger, better-constrained Cenozoic orogens.

\section{Conclusions}


Accretionary orogenesis is a key process of stabilization and formation of the continental lithosphere. Terrane theory and terrane analysis represent the framework for understanding the processes of crustal accretion. The "Australides" are one of the largest and longest-lived orogens on Earth and have been a key testing ground for the origination and development of terrane theory. Terrane studies continue to be a vibrant and active area of research in the "Australides”, with new techniques and insights emerging on a regular basis. Many research groups from North and South America, Europe and Oceania are active in the region, whose work has provided deep insights into the Proterozoic and Phanerozoic evolution of the orogen and the fundamentals of accretionary orogenesis. The “Australides” are a key area for terrane research and here we have attempted to capture the current state of ideas and provide an introduction and benchmark for future research.

The papers in this volume stemmed from work presented at the "Terrane Processes at the Pacific Margin of Gondwana" meeting held in Cambridge, UK in September 2003 and at the $10^{\text {th }}$ Chilean Geological Congress held in Concepción in October 2003, as well as invited contributions. This volume is a contribution to the British Antarctic Survey SPARC project of the programme Antarctica in the Dynamic Global Plate System and a posthumous contribution to International Geological Correlation Project 436 "Pacific Gondwana margin". We thank Robert Hall and Brendan Murphy for thoughtful reviews that substantially improved the manuscript.

\section{References}

AALTO, K.R. 1981. Multistage melange formation in the Franciscan complex, northernmost California. Geology, 9 (12), 602-607.

AbBott, L.D., Silver, E.A., Thompson, P.R., Filewicz, M.V., SCHneider, C. \& ABDOERRIAS, R. 1994. Stratigraphic constraints on the development and timing of arc-continent collision in northern Papua New Guinea. Journal of Sedimentary Research, 64, 169-183.

AbDelsalam, M.G., AbDeEn, M.M., Dowaidar, H.M., Stern, R.J. \& ABDELGHAFFAR, A.A. 2003. Structural evolution of the Neoproterozoic 
western Allaqi-Heiani suture, southeastern Egypt. Precambrian Research, 124 (1), 87-104.

AceñolazA, F.G., Miller, H. \& Toselli, A.J. 2002. Proterozoic-Early Paleozoic evolution in western South America: a discussion. Tectonophysics, 354 (1-2), 121-137.

Adams, C.J., BARley, M.E., Fletcher, I.R. \& Pickard, A.L. 1998. Evidence from $\mathrm{U}-\mathrm{Pb}$ zircon and ${ }^{40} \mathrm{Ar} /{ }^{39} \mathrm{Ar}$ muscovite detrital mineral ages in metasandstones for the movement of the Torlesse suspect terrane around the eastern margin of Gondwanaland. Terra Nova, 10, 183-189.

AdAms, C.J., BARLey, M.E., MAAs, R. \& Doyle, M.G. 2002. Provenance of Permian-Triassic volcaniclastic sedimentary terranes in New Zealand: evidence from their radiogenic isotope characteristics and detrital mineral age patterns. New Zealand Journal of Geology and Geophysics, 45 (2), 221-242.

Adams, C.J. \& Kelley, S. 1998. Provenance of Permian-Triassic and Ordovician metagraywacke terranes in New Zealand: Evidence from ${ }^{40} \mathrm{Ar} /{ }^{39} \mathrm{Ar}$ dating of detrital micas. Geological Society of America Bulletin, 110 (4), 422-432.

AdAms, C.J., PANKhurst, R.J., MAAS, R. \& Millar, I.L. 2005. Nd and Sr isotopic signatures of metasedimentary rocks around the South Pacific margin, and implications for their provenance. In: VAUGHAN, A.P.M., LEAT, P.T. \& PANKHURST, R.J. (eds) Terrane Processes at the Margins of Gondwana. Geological Society, London, Special Publications, this volume.

Aitchison, J.C., Abrajevitch, A., Ali, J.R., Badengzhu, Davis, A.M., LuO, H., LiU, J.B., MCDERMID, I.R.C. \& ZiABREV, S. 2002. New insights into the evolution of the Yarlung Tsangpo suture zone, Xizang (Tibet), China. Episodes, 25 (2), 90-94.

Armadillo, E., Ferraccioli, F., TABellario, G. \& Bozzo, E. 2004. Electrical structure across a major ice-covered fault belt in Northern Victoria Land (East Antarctica). Geophysical Research Letters, 31 (10), 1-4, L10615, 10.1029/2004GL019903.

Astini, R.A., BenEDETTO, J.L. \& VACCARI, N.E. 1995. The Early Paleozoic evolution of the Argentine Precordillera as a Laurentian rifted, drifted, and collided terrane: a geodynamic model. Geological Society of America Bulletin, 107 (3), 253-273.

Badarch, G., Cunningham, W.D. \& Windley, B.F. 2002. A new terrane subdivision for Mongolia: implications for the Phanerozoic crustal growth of Central Asia. Journal of Asian Earth Sciences, 21 (1), 87-110.

Bandres, A., Eguiluz, L., IbARguchi, J.I.G. \& Palacios, T. 2002. Geodynamic evolution of a Cadomian arc region: the northern Ossa-Morena zone, Iberian massif. Tectonophysics, 352 (1-2), 105-120.

BARKER, F., JONES, D.L., BUDAHN, J.R. \& CONEY, P.J. 1988. Ocean plateauseamount origin of basaltic rocks, Angayucham terrane, Central Alaska. Journal of Geology, 96 (3), 368-374.

BARR, S.M. 1990. Granitoid rocks and terrane characterization: an example from the northern Appalachian orogen. Geological Journal, 25 (3-4), 295-304.

BÉDARD, J.H. 1999. Petrogenesis of boninites from the Betts Cove Ophiolite, Newfoundland, Canada: Identification of subducted source components. Journal of Petrology, 40 (12), 1853-1889.

Belasky, P., Stevens, C.H. \& Hanger, R.A. 2002. Early Permian location of western North American terranes based on brachiopod, fusulinid, and coral 
biogeography. Palaeogeography Palaeoclimatology Palaeoecology, 179 (3-4), 245-266.

BENEDETTO, J.L. 1998. Caradocian brachiopods from the glacigenic diamictite of the Don Braulio Formation (Late Ashgillian), Sierra de Villicum, Argentine Precordillera. Ameghiniana, 35 (3), 243-254.

BERG, H.C., Jones, D.L. \& RichTER, D.H. 1972. Gravina-Nutzotin belt-tectonic significance of an upper Mesozoic sedimentary and volcanic sequence in southern and southeastern Alaska United States Geological Survey Professional Papers, 800-D, D1-D24.

Bernasconi, A. 1987. The major Precambrian terranes of eastern South America: a study of their regional and chronological evolution. Precambrian Research, 37 (2), 107-124.

Betts, P.G., Giles, D., Lister, G.S. \& Frick, L.R. 2002. Evolution of the Australian lithosphere. Australian Journal of Earth Sciences, 49 (4), 661-695.

BLAKE, M.C., JR., JONES, D.L. \& LANDIS, C.A. 1974. Active continental margins: contrasts between California and New Zealand. In: BURK, C.A. \& DRAKE, C.L. (eds) The Geology of Continental Margins. Springer-Verlag, New York, 853-871.

BLUCK, B.J. 1990. Terrane provenance and amalgamation: examples from the Caledonides. Philosophical Transactions of the Royal Society of London Series A, 331, 599-609.

Bluck, B.J., Halliday, A.N., Aftalion, M. \& Macintyre, R.M. 1980. Age and origin of the Ballantrae ophiolite and its significance to the Caledonian orogeny and the Ordovician timescale. Geology, 8, 492-495.

BODET, F. \& SCHÄRER, U. 2000. Evolution of the SE-Asian continent from U-Pb and $\mathrm{Hf}$ isotopes in single grains of zircon and baddeleyite from large rivers. Geochimica et Cosmochimica Acta, 64, 2067-2091.

Boger, S.D., CARson, C.J., FAnNing, C.M., Hergt, J.M., Wilson, C.J.L. \& WoODHEAD, J.D. 2002. Pan-African intraplate deformation in the northern Prince Charles Mountains, east Antarctica. Earth and Planetary Science Letters, 195 (3-4), 195-210.

Boger, S.D., Wilson, C.J.L. \& FAnNing, C.M. 2001. Early Paleozoic tectonism within the East Antarctic craton: The final suture between east and west Gondwana? Geology, 29 (5), 463-466.

BRADSHAW, J.D. 1989. Cretaceous geotectonic patterns in the New Zealand region. Tectonics, 8, 803-820.

Bradshaw, J.D. 1994. Brook Street and Murihiku terranes of New Zealand in the context of a mobile South Pacific Gondwana margin. Journal of South American Earth Sciences, 7 (3-4), 325-332.

Bradshaw, J.D., ANDREwS, P.B. \& ADAMS, C.J. 1981. Carboniferous to Cretaceous on the Pacific margin of Gondwana: the Rangitata Phase of New Zealand. In: Creswell, M.M. \& Vella, P. (eds) Gondwana Five. Balkema, Rotterdam, 217-221.

BRown, L.D. 1991. A new map of crustal terranes in the United States from COCORP deep seismic reflection profiling. Geophysical Journal International, 105 (1), 3-13.

BRYAn, S.E., Holcombe, R.J. \& FIELDING, C.R. 2001. Yarrol terrane of the northern New England Fold Belt: forearc or backarc? Australian Journal of Earth Sciences, 48 (2), 293-316. 
CAmpbell, H.J., Mortimer, N. \& Raine, J.I. 2001. Geology of the Permian Kuriwao Group, Murihiku Terrane, Southland, New Zealand. New Zealand Journal of Geology and Geophysics, 44 (4), 485-498.

Carayon, V., DeWeVer, P. \& RaOUlT, J.F. 1984. Franciscan limestone knockers from southwestern Oregon: a new interpretation on melange genesis. Comptes Rendus De L Academie Des Sciences Serie II, 298 (16), 709-714.

Casquet, C., Baldo, E., Pankhurst, R.J., Rapela, C.W., Galindo, C., FAnNing, C.M. \& SAAVEDRA, J. 2001. Involvement of the Argentine Precordillera terrane in the Famatinian mobile belt: U-PbSHRIMP and metamorphic evidence from the Sierra de Pie de Palo. Geology, 29 (8), 703-706.

Casquet, C., Pankhurst, R.J., Rapela, C.W., Galindo, C., DAhQuist, J., Baldo, E., SAAVEDRA, J., GONZÁlez CASAdO, J.-M. \& FANNinG, C.M. in press. Grenvillian massif anorthosites in the Sierras Pampeanas. Journal of the Geological Society, London.

Cawood, P.A., Landis, C.A., Nemchin, A.A. \& HadA, S. 2002. Permian fragmentation, accretion and subsequent translation of a low-latitude Tethyan seamount to the high-latitude east Gondwana margin: evidence from detrital zircon age data. Geological Magazine, 139, 131-144.

CAWOOD, P.A. \& LEITCH, E.C. 2002. Terra Australis orogen: Rodinian breakup and subduction initiation in the Pacific Ocean. Geological Society of Australia, Abstracts, 65, 13-15.

Cawood, P.A., Nemchin, A.A., Leverenz, A., Saeed, A. \& Ballance, P. 1999. U$\mathrm{Pb}$ dating of detrital zircons: implications for the provenance record of Gondwana margin terranes. Geological Society of America Bulletin, 111, 1107-1119.

CAwOOD, P.A. \& SuHR, G. 1992. Generation and obduction of ophiolites: constraints from the Bay of Islands complex, western Newfoundland. Tectonics, 11, 884897.

Chang, C.P., Angelier, J., HuAng, C.Y. \& LiU, C.S. 2001. Structural evolution and significance of a melange in a collision belt: the Lichi Melange and the Taiwan arc-continent collision. Geological Magazine, 138 (6), 633-651.

ChernicofF, C.J. \& ZAPPETTINI, E.O. 2003. Delimitation of tectonostratigraphic terranes of the southern-central region of Argentina: aeromagnetic evidences. Revista Geologica de Chile, 30 (2), 299-316.

ClifT, P.D. \& RYAN, P.D. 1994. Geochemical evolution of an Ordovician island arc, south Mayo, Ireland. Journal of the Geological Society, London, 151, 329342.

Cloos, M. 1983. Comparative study of melange matrix and metashales from the Franciscan subduction complex with the basal Great Valley sequence, California. Journal of Geology, 91 (3), 291-306.

COCKS, L.R.M. \& TORSVIK, T.H. 2002. Earth geography from 500 to 400 million years ago: a faunal and palaeomagnetic review. Journal of the Geological Society, 159, 631-644.

Collins, W.J. 1991. A reassessment of the Hunter-Bowen orogeny: tectonic implications for the southern New England fold belt. Australian Journal of Earth Sciences, 38 (4), 409-423.

Condie, K.C. \& CHOMiAK, B. 1996. Continental accretion: contrasting Mesozoic and Early Proterozoic tectonic regimes in North America. Tectonophysics, 265 (12), 101-126. 
Coney, P.J. 1978. Mesozoic-Cenozoic Cordilleran plate tectonics. In: SMITH, R.B. \& EATON, G.P. (eds) Cenozoic Tectonics and Regional Geophysics of the Western Cordillera. Geological Society of America Memoirs, 152, 33-50.

Coney, P.J., Edwards, A., Hine, R., Morrison, F. \& Windrim, D. 1990. The regional tectonics of the Tasman orogenic system, eastern Australia. Journal of Structural Geology, 12 (5-6), 519-543.

Coney, P.J., Jones, D.L. \& MongeR, J.W.H. 1980. Cordilleran suspect terranes. Nature, 288, 329-333.

CoOMBS, D.S. 1997. A note on the terrane concept, based on a introduction to the Terrane '97 conference, Christchurch, New Zealand, February 1997. American Journal of Science, 297 (7), 762-764.

COOMBS, D.S., LANDis, C.A., NorRis, R.J., SinTON, J.M., BORNS, D.J. \& CRAW, D. 1976. The Dun Mountain ophiolite belt, New Zealand, its tectonic setting, constitution, and origin, with special reference to the southern portion. American Journal of Science, 276, 561-603.

Cordani, U.G., Cardona, A., Jimenez, D.M., LiU, D. \& Nutman, A.P. 2005. Geochronology of Proterozoic basement inliers in the Colombian Andes: tectonic history of remnants of a fragmented Grenville belt. In: VAUGHAN, A.P.M., LEAT, P.T. \& PANKHURST, R.J. (eds) Terrane Processes at the Margins of Gondwana. Geological Society. London, Special Publications, this volume.

Cowan, D.S., Brandon, M.T. \& GARVER, J.I. 1997. Geologic tests of hypotheses for large coastwise displacements: a critique illustrated by the Baja British Columbia controversy. American Journal of Science, 297 (2), 117-173.

CuRTIS, M.L. 2001. Tectonic history of the Ellsworth Mountains, West Antarctica: reconciling a Gondwana enigma. Geological Society of America Bulletin, 113 (7), 939-958.

DALZIEL, I.W.D. \& ELLIOT, D.H. 1982. West Antarctica: problem child of Gondwanaland. Tectonics, 1, 3-19.

DANNER, W.R. 1970. Paleontologic and stratigraphic evidence for and against sea floor spreading and opening and closing oceans in the Pacific Northwest. Geological Society of America Abstracts with Programs, 2 (2), 84-85.

DeBARI, S.M. \& SLEeP, N.H. 1991. High-Mg, low-Al bulk composition of the Talkeetna island arc, Alaska: implications for primary magmas and the nature of arc crust. Geological Society of America Bulletin, 103 (1), 37-47.

Defant, M.J., KePEZhinskas, P., XU, J.F., WANG, Q., Zhang, Q. \& XIAO, L. 2002. Adakites: some variations on a theme. Acta Petrologica Sinica, 18 (2), 129142.

DireEn, N.G. \& CRAWFORD, A.J. 2003. Fossil seaward-dipping reflector sequences preserved in southeastern Australia: a 600 Ma volcanic passive margin in eastern Gondwanaland. Journal of the Geological Society, London, 160 (6), 985-990.

Doubleday, P.A., Leat, P.T., Alabaster, T., Nell, P.A.R. \& Tranter, T.H. 1994. Allochthonous oceanic basalts within the Mesozoic accretionary complex of Alexander Island, Antarctica: remnants of proto-Pacific oceanic crust. Journal of the Geological Society, London, 151 (1), 65-78.

ERNST, W.G. 1993. Metamorphism of Franciscan tectonostratigraphic assemblage, Pacheco Pass area, east-central Diablo Range, California Coast Ranges. Geological Society of America Bulletin, 105 (5), 618-636. 
Fang, Z.-J., Boucot, A., Covacevich, V. \& Hervé, F. 1998. Discovery of Late Triassic fossils in the Chonos Metamorphic Complex, Southern Chile. Revista Geológica de Chile, 25, 165-173.

FAugeres, J.C., GONTHIER, E., GRIBOUlard, R. \& MASSE, L. 1993. Quaternary sandy deposits and canyons on the Venezuelan margin and south Barbados accretionary prism. Marine Geology, 110 (1-2), 115-142.

FERGUSSON, C.L. 2003. Ordovician-Silurian accretion tectonics of the Lachlan Fold Belt, southeastern Australia. Australian Journal of Earth Sciences, 50 (4), 475-490.

FERGUSSON, C.L. \& FANNING, C.M. 2002. Late Ordovician stratigraphy, zircon provenance and tectonics, Lachlan Fold Belt, southeastern Australia. Australian Journal of Earth Sciences, 49 (3), 423-436.

FERRACCIOLI, F. \& Bozzo, E. 1999. Inherited crustal features and tectonic blocks of the Transantarctic Mountains: An aeromagnetic perspective (Victoria Land, Antarctica). Journal of Geophysical Research, 104 (B11), 25297-25319.

FERrACCIOLI, F., Bozzo, E. \& CAPPONI, G. 2002. Aeromagnetic and gravity anomaly constraints for an early Paleozoic subduction system of Victoria Land, Antarctica. Geophysical Research Letters, 29 (10), 1-4, 1406, 10.1029/2001GL014138.

Finney, S.C., Peralta, S.H., Gehrels, G.E. \& Marsaglia, K.M. in press. The Early Paleozoic history of the Cuyania (greater Precordillera) terrane of western Argentina: evidence from geochronology of detrital zircons from Middle Cambrian sandstones. Geologica Acta.

FISKE, R.S., NAKA, J., IIZASA, K., YuASA, M. \& KlaUS, A. 2001. Submarine silicic caldera at the front of the Izu-Bonin arc, Japan: voluminous seafloor eruptions of rhyolite pumice. Geological Society of America Bulletin, 113 (7), 813-824.

Fitzherbert, J.A., Clarke, G.L., MARmo, B. \& Powell, R. 2004. The origin and $\mathrm{P}-\mathrm{T}$ evolution of peridotites and serpentinites of NE New Caledonia: prograde interaction between continental margin and the mantle wedge. Journal of Metamorphic Geology, 22 (4), 327-344.

FITZSIMONS, I.C.W. 2000a. Grenville-aged basement provinces in East Antarctica: evidence for at least three separate collisional orogens. Geology, 28, 879-882.

FITZSIMONS, I.C.W. 2000b. A review of tectonic events in the East Antarctic Shield and their implications for Gondwana and earlier supercontinents. Journal of African Earth Sciences, 31 (1), 3-23.

Flöttmann, T., Gibson, G.M. \& KlEInSChMidT, G. 1993. Structural continuity of the Ross and Delamerian orogens of Antarctica and Australia along the margin of the proto-Pacific. Geology, 21, 319-322.

Foster, D.A. \& GrAY, D.R. 2000. Evolution and structure of the Lachlan fold belt (orogen) of eastern Australia. Annual Review of Earth and Planetary Sciences, 28, 47-80.

Fouquet, Y., Vonstackelberg, U., Charlou, J.L., Donval, J.P., ERzinger, J., FouCher, J.P., HERziG, P., MuHE, R., SOAKAI, S., WiEDICKE, M. \& WhiteChuRCH, H. 1991. Hydrothermal activity and metallogenesis in the Lau back-arc basin. Nature, 349 (6312), 778-781.

FriedL, G., Finger, F., McNaughton, N.J. \& Fletcher, I.R. 2000. Deducing the ancestry of terranes: SHRIMP evidence for South America-derived Gondwana fragments in central Europe. Geology, 28, 1035-1038. 
Friend, C.R.L., NutMAn, A.P. \& McGregor, V.R. 1988. Late Archean terrane accretion in the Godthab region, southern West Greenland. Nature, 335, 535538.

FRITZ, H. 1996. Geodynamic and tectonic evolution of the southeastern Bohemian Massif: The Thaya section (Austria). Mineralogy and Petrology, 58 (3-4), 253-278.

FuH, S.-C., LiU, C.-S., LunDBERG, N. \& REED, D.L. 1997. Strike-slip faults offshore southern Taiwan: implications for the oblique arc-continent collision process. Tectonophysics, 274, 25-39.

Gaetani, M., Zanchi, A., Angiolini, L., Olivini, G., Sciunnach, D., Brunton, H., NicorA, A. \& MAWson, R. 2004. The Carboniferous of the Western Karakoram (Pakistan). Journal of Asian Earth Sciences, 23 (2), 275-305.

Gardner, M.C., Bergman, S.C., Cushing, G.W., Mackevett, E.M., Plafker, G., CAmpBell, R.B., Dodds, C.J., McClelland, W.C. \& Mueller, P.A. 1988. Pennsylvanian pluton stitching of Wrangellia and the Alexander terrane, Wrangell Mountains, Alaska. Geology, 16 (11), 967-971.

GLEN, R.A. 2005. The Tasmanides of eastern Australia: 600 million years of interaction between the proto-Pacific plate and the Australian sector of Gondwana. In: VAughan, A.P.M., LEAT, P.T. \& PANKHURST, R.J. (eds) Terrane Processes at the Margins of Gondwana. Geological Society, London, Special Publications, this volume.

Glen, R.A., WALshe, J.L., BARRON, L.M. \& WATKINS, J.J. 1998. Ordovician convergent-margin volcanism and tectonism in the Lachlan sector of east Gondwana. Geology, 26 (8), 751-754.

GoldFARB, R.J., Groves, D.I. \& GARDOLL, S. 2001. Orogenic gold and geologic time: a global synthesis. Ore Geology Reviews, 18 (1-2), 1-75.

Gower, C.F. \& KROGH, T.E. 2002. A U-Pb geochronological review of the Proterozoic history of the eastern Grenville Province. Canadian Journal of Earth Sciences, 39 (5), 795-829.

Griffin, W.L., Belousova, E.A., Shee, S.R., Pearson, N.J. \& O'Reilly, S.Y. 2004. Archean crustal evolution in the northern Yilgam Craton: U-Pb and Hfisotope evidence from detrital zircons. Precambrian Research, 131 (3-4), 231282.

HALL, R. 2002. Cenozoic geological and plate tectonic evolution of SE Asia and the SW Pacific: computer-based reconstructions, model and animations. Journal of Asian Earth Sciences, 20 (4), 353-431.

HandleR, M.R., Wysoczanski, R.J. \& GAmble, J.A. 2003. Proterozoic lithosphere in Marie Byrd Land, West Antarctica: Re-Os systematics of spinel peridotite xenoliths. Chemical Geology, 196 (1-4), 131-145.

HARTZ, E.H. \& TORSVIK, T.H. 2002. Baltica upside down: A new plate tectonic model for Rodinia and the Iapetus Ocean. Geology, 30 (3), 255-258.

Heatherington, A.L. \& Mueller, P.A. 2003. Mesozoic igneous activity in the Suwannee terrane, southeastern USA: petrogenesis and Gondwanan affinities. Gondwana Research, 6 (2), 296-311.

Herrmann, U.R., Nelson, B.K. \& RAtSchbacher, L. 1994. The origin of a terrane: $\mathrm{U}-\mathrm{Pb}$ zircon geochronology and tectonic evolution of the Xolapa complex (southern Mexico). Tectonics, 13 (2), 455-474.

HERVÉ, F. 1988. Late Paleozoic subduction and accretion in Southern Chile. Episodes, 11, 183-188. 
HeRVÉ, F. \& FANNING, C.M. 2001. Late Triassic detrital zircons in meta-turbidites of the Chonos Metamorphic Complex, southern Chile. Revista Geologica de Chile, 28 (1), 91-104.

HERVÉ, F. \& FANNING, C.M. 2003. Early Cretaceous subduction of continental crust at the Diego de Almagro archipelago, southern Chile. Episodes, 26 (4), 285288.

Hervé, F., FAnNing, C.M. \& PANKhuRst, R.J. 2003. Detrital zircon age patterns and provenance of the metamorphic complexes of southern Chile. Journal of South American Earth Sciences, 16 (1), 107-123.

HerziG, C.T. \& ShARP, W.D. 1992. The Sullivan Creek terrane: a composite Jurassic arc assemblage, western Sierra Nevada metamorphic belt, California. Geological Society of America Bulletin, 104 (10), 1292-1300.

HiBBARD, J. 2000. Docking Carolina: mid-Paleozoic accretion in the southern Appalachians. Geology, 28 (2), 127-130.

Hibbard, J.P., Miller, B., Tracy, R. \& CARTer, B. 2005. The Appalachian periGondwanan realm: a palaeogeographic perspective from the south. In: VAughan, A.P.M., LeAT, P.T. \& PANKHURST, R.J. (eds) Terrane Processes at the Margins of Gondwana. Geological Society, London, Special Publications, this volume.

Hill, M.L. \& DibBleE, T.W., JR. 1953. San Andreas, Garlock, and Big Pine faults, California: a study of the character, history, and tectonic significance of their displacements. Geological Society of America Bulletin, 64, 443-458.

HowelL, D.G. 1980. Mesozoic accretion of exotic terranes along the New Zealand segment of Gondwanaland. Geology, 8 (10), 487-491.

HowELL, D.G. 1989. Tectonics of Suspect Terranes: Mountain Building and Continental Growth. Chapman \& Hall, London.

Howell, D.G., JonES, D.L. \& SCHERMER, E.R. 1985. Tectonostratigraphic terranes of the Circum-Pacific region. In: HowELL, D.G. (ed.) Tectonostratigraphic Terranes of the Circum-Pacific Region. Council for Energy and Mineral Resources, Earth Science Series, 1, 3-30.

Howell, K. \& Howell, D.G. 1995. Principles of Terrane Analysis: New Applications for Global Tectonics. Chapman \& Hall, New York.

HutTON, D.H.W. 1987. Strike-slip terranes and a model for the evolution of the British and Irish Caledonides. Geological Magazine, 124 (5), 405-425.

IIZASA, K., Fiske, R.S., IsHIZUKA, O., YUASA, M., HASHIMOTO, J., ISHIBASHI, J., NAKA, J., HoriI, Y., FuJIWARA, Y., IMAI, A. \& KoYAmA, S. 1999. A Kurokotype polymetallic sulfide deposit in a submarine silicic caldera. Science, $\mathbf{2 8 3}$ (5404), 975-977.

Ireland, T.R., Flottmann, T., Fanning, C.M., Gibson, G.M. \& Preiss, W.V. 1998. Development of the early Paleozoic Pacific margin of Gondwana from detrital-zircon ages across the Delamerian orogen. Geology, 26 (3), 243-246.

IRWIN, W.P. 1964. Late Mesozoic orogenies in the ultramafic belts of northwestern California and southwestern Oregon United States Geological Survey Professional Papers, 501-C, C1-C9.

IRWIN, W.P. 1972. Terranes of the western Paleozoic and Triassic belt in the southern Klamath Mountains, California United States Geological Survey Professional Papers, 800-C, C103-C111.

ISHIBASHI, J. \& URABE, T. 1995. Hydrothermal activity related to arc-backarc magmatism in the Western Pacific. In: TAYLOR, B. (ed.) Backarc Basins: Tectonics and Magmatism. Plenum Press, New York, 451-495. 
JACOBI, R.D. \& WASOWSKI, J.J. 1985. Geochemistry and plate tectonic significance of the volcanic rocks of the Summerford Group, north-central Newfoundland. Geology, 13 (2), 126-130.

JacoBs, J., FAnNing, C.M. \& BAUER, W. 2003. Timing of Grenville-age vs PanAfrican medium- to high grade metamorphism in western Dronning Maud Land (East Antarctica) and significance for correlations in Rodinia and Gondwana. Precambrian Research, 125 (1-2), 1-20.

Johnson, P.R., AbDelsalam, M.G. \& SteRn, R.J. 2003. The Bi'r Umq-Nakasib suture zone in the Arabian-Nubian shield: a key to understanding crustal growth in the East African orogen. Gondwana Research, 6 (3), 523-530.

JoHNSTON, S.T. 2001. The great Alaskan terrane wreck: reconciliation of paleomagnetic and geological data in the northern Cordillera. Earth and Planetary Science Letters, 193 (3-4), 259-272.

KAMP, P.J.J. 2000. Thermochronology of the Torlesse accretionary complex, Wellington region, New Zealand. Journal of Geophysical Research, 105 (B8), 19253-19272.

Kapp, P., Yin, A., MANning, C.E., Harrison, T.M., TAYlOR, M.H. \& Ding, L. 2003. Tectonic evolution of the early Mesozoic blueschist-bearing Qiangtang metamorphic belt, central Tibet. Tectonics, 22 (4), 1-25, 1043, 10.1029/2002TC001383.

KAWATE, S. \& ARIMA, M. 1998. Petrogenesis of the Tanzawa plutonic complex, central Japan: exposed felsic middle crust of the Izu-Bonin-Mariana arc. Island Arc, 7 (3), 342-358.

KAY, R.W. \& KAY, S.M. 2002. Andean adakites: three ways to make them. Acta Petrologica Sinica, 18 (3), 303-311.

Kelly, S.R.A., Doubleday, P.A., Brunton, C.H.C., Dickins, J.M., SEVAstopulO, G.D. \& TAYLOR, P.D. 2001. First Carboniferous and ?Permian marine macrofaunas from Antarctica and their tectonic implications. Journal of the Geological Society, London, 158 (2), 219-232.

KenNEDY, W.Q. 1946. The Great Glen Fault. Quarterly Journal of the Geological Society, 102, 41-76.

KePPIE, J.D. 1985a. The Appalachian Collage. In: GeE, D.G. \& SturT, B.A. (eds) The Caledonide Orogen - Scandinavia and Related Areas. John Wiley, Chichester, 1217-1226.

KePPIE, J.D. 1985b. Geology and tectonics of Nova Scotia. In: KePPIE, J.D., CuRRIE, K., Murphy, J.B., PiCKerill, R.K., FyfFe, L. \& ST. Julian, P. (eds) Excursion 1: Appalachian Geotraverse. Geological Association of Canada/Mineralogical Association of Canada, Fredericton, 1-181.

KEPPIE, J.D. \& DALlMEYER, R.D. 1987. Dating transcurrent terrane accretion: an example from the Meguma and Avalon composite terranes in the northern Appalachians. Tectonics, 6 (6), 831-847.

KePPIE, J.D. \& DosTAL, J. 2001. Evaluation of the Baja controversy using paleomagnetic and faunal data, plume magmatism, and piercing points. Tectonophysics, 339 (3-4), 427-442.

Keppie, J.D., NANCE, R.D., MurPhy, J.B. \& Dostal, J. 2003. Tethyan, Mediterranean, and Pacific analogues for the Neoproterozoic-Paleozoic birth and development of peri- Gondwanan terranes and their transfer to Laurentia and Laurussia. Tectonophysics, 365 (1-4), 195-219. 
KerRich, R., Goldfarb, R., Groves, D., Garwin, S. \& Jia, Y. 2000. The characteristics, origins, and geodynamic settings of supergiant gold metallogenic provinces. Science in China Series D-Earth Sciences, 43, 1-68.

KimurA, G., SAKAKIBARA, M. \& OKAMURA, M. 1994. Plumes in central Panthalassa: deductions from accreted oceanic fragments in Japan. Tectonics, 13 (4), 905916.

Knudsen, T.L., Griffin, W.L., Hartz, E.H., Andresen, A. \& JACKSON, S.E. 2001. In-situ hafnium and lead isotope analyses of detrital zircons from the Devonian sedimentary basin of NE Greenland: a record of repeated crustal reworking. Contributions to Mineralogy and Petrology, 141 (1), 83-94.

KotTachchi, N., Schroder-Adams, C.J., Haggart, J.W. \& Tipper, H.W. 2002. Jurassic foraminifera from the Queen Charlotte Islands, British Columbia, Canada: biostratigraphy, paleoenvironments and paleogeographic implications. Palaeogeography Palaeoclimatology Palaeoecology, 180 (1-3), 93-127.

KuSKY, T.M. \& BRADLEY, D.C. 1999. Kinematic analysis of melange fabrics: examples and applications from the McHugh Complex, Kenai Peninsula, Alaska. Journal of Structural Geology, 21 (12), 1773-1796.

LAIRD, M.G. \& BRADSHAW, J.D. 2004. The break-up of a long-term relationship: the Cretaceous separation of New Zealand from Gondwana. Gondwana Research, 7 (1), 273-286.

LAPIERRE, H., Bosch, D., TARDY, M. \& STRUIK, L.C. 2003. Late Paleozoic and Triassic plume-derived magmas in the Canadian Cordillera played a key role in continental crust growth. Chemical Geology, 201 (1-2), 55-89.

Lapierre, H., Tardy, M., Coulon, C., Hernandez, E.O., Bourdier, J.L., Reyes, J.M. \& FREYDIER, C. 1992. Characterization, genesis and geodynamic evolution of Guerrero terrane (western Mexico). Canadian Journal of Earth Sciences, 29 (11), 2478-2489.

Leat, P.T., Dean, A.A., Millar, I.L., Kelley, S.P., VAughan, A.P.M. \& Riley, T.R. 2005. Lithospheric mantle domains beneath Antarctica. In: VAUGHAN, A.P.M., LEAT, P.T. \& PANKHURST, R.J. (eds) Terrane Processes at the Margins of Gondwana. Geological Society, London, Special Publications, this volume.

Ledo, J., Jones, A.G., Ferguson, I.J. \& Wolynec, L. 2004. Lithospheric structure of the Yukon, northern Canadian Cordillera, obtained from magnetotelluric data. Journal of Geophysical Research, 109 (B4), 1-19, B04410, 10.1029/2003JB002516.

LEGGETT, J.K. 1987. The Southern Uplands as an accretionary prism: the importance of analogues in reconstructing palaeogeography. Journal of the Geological Society, London, 144 (4), 737-752.

Lehmann, D., Brett, C.E., Cole, R. \& Baird, G. 1995. Distal sedimentation in a peripheral foreland basin: Ordovician black shales and associated flysch of the western Taconic foreland, New York State and Ontario. Geological Society of America Bulletin, 107 (6), 708-724.

LeITCH, E.C., FERGusson, C.L. \& Henderson, R.A. 2003. Arc to craton provenance switching in a Late Palaeozoic subduction complex, Wandilla and Shoalwater terranes, New England Fold Belt, eastern Australia. Australian Journal of Earth Sciences, 50 (6), 919-929.

LEVERENZ, A. \& BALLANCE, P.F. 2001. Terrane affiliation and terrane boundaries of Mesozoic accretionary complexes, northeastern North Island, New Zealand: 
some implications from recycled clastics. New Zealand Journal of Geology and Geophysics, 44 (4), 589-599.

LuCAssen, F. \& Franz, G. 2005. The early Palaeozoic orogen in the Central Andes: a non-collisional orogen comparable to the Cenozoic high plateau? In: VAughan, A.P.M., LeAt, P.T. \& PANKHuRst, R.J. (eds) Terrane Processes at the Margins of Gondwana. Geological Society, London, Special Publications, this volume.

MacDonald, A.J., Lewis, P.D., Thompson, J.F.H., NAdAraJu, G., Bartsch, R.D., BRIDGE, D.J., RhYs, D.A., Roth, T., KAIP, A., GODWIN, C.I. \& SinClAIR, A.J. 1996. Metallogeny of an early to middle Jurassic arc, Iskut river area, northwestern British Columbia. Economic Geology, 91 (6), 1098-1114.

MaeKaWA, H., Yamamoto, K., Ueno, T., Osada, Y. \& Nogami, N. 2004. Significance of serpentinites and related rocks in the high- pressure metamorphic terranes, circum-Pacific regions. International Geology Review, 46 (5), 426-444.

Mankinen, E.A., IRWIN, W.P. \& Blome, C.D. 1996. Far-travelled Permian chert of the North Fork terrane, Klamath Mountains, California. Tectonics, 15 (2), 314-328.

MARSAGLIA, K.M. \& INGERSOLL, R.V. 1992. Compositional trends in arc-related, deep-marine sand and sandstone: a reassessment of magmatic arc provenance. Geological Society of America Bulletin, 104 (12), 1637-1649.

MatTe, P. 2001. The Variscan collage and orogeny (480-290 Ma) and the tectonic definition of the Armorica microplate: a review. Terra Nova, 13 (2), 122-128.

McClelland, W.C., Gehrels, G.E. \& SAleEBY, J.B. 1992. Upper Jurassic-Lower Cretaceous basinal strata along the Cordilleran margin: implications for the accretionary history of the Alexander-Wrangellia-Peninsular terrane. Tectonics, 11 (4), 823-835.

McElhinny, M.W., Powell, C.M. \& Pisarevsky, S.A. 2003. Paleozoic terranes of eastern Australia and the drift history of Gondwana. Tectonophysics, 362 (14), 41-65.

MetcalfE, I. 1994. Gondwanaland origin, dispersion, and accretion of east and Southeast Asian continental terranes. Journal of South American Earth Sciences, 7 (3-4), 333-347.

MiLLAR, I.L. \& PANKHURST, R.J. 1987. Rb-Sr geochronology of the region between the Antarctic Peninsula and the Transantarctic Mountains: Haag Nunataks and Mesozoic granitoids. In: McKenzIE, G.D. (ed.) Gondwana Six: Structure, Tectonics, and Geophysics. Geophysical Monographs, 40, 151-160.

Millar, I.L., PANKhuRst, R.J. \& FAnNinG, C.M. 2002. Basement chronology of the Antarctic Peninsula: recurrent magmatism and anatexis in the Palaeozoic Gondwana margin. Journal of the Geological Society, London, 159 (2), 145157.

Millar, I.L., Willan, R.C.R., WAREham, C.D. \& BoyCE, A.J. 2001. The role of crustal and mantle sources in the genesis of granitoids of the Antarctic Peninsula and adjacent crustal blocks. Journal of the Geological Society, London, 158 (5), 855-867.

Miller, D.J. \& CHRISTENSEN, N.I. 1994. Seismic signature and geochemistry of an island arc: a multidisciplinary study of the Kohistan accreted terrane, northern Pakistan. Journal of Geophysical Research-Solid Earth, 99 (B6), 1162311642. 
Miller, H. \& Söllner, F. 2005. The Famatina complex (NW Argentina): backdocking of an island arc or terrane accretion? Early Palaeozoic geodynamics at the western Gondwana margin. In: VAUGHAN, A.P.M., LEAT, P.T. \& PANKHURST, R.J. (eds) Terrane Processes at the Margins of Gondwana. Geological Society, London, Special Publications, this volume.

MilsOM, J., Ali, J. \& SuDARWONO 1999. Structure and collision history of the Buton continental fragment, eastern Indonesia. AAPG Bulletin, 83 (10), 1666-1689.

MONGER, J.W.H. 1997. Plate tectonics and northern cordilleran geology: an unfinished revolution. Geoscience Canada, 24 (4), 189-198.

Monger, J.W.H., SOUTHER, J.G. \& GABRIELSE, H. 1972. Evolution of the Canadian Cordillera: a plate tectonic model. American Journal of Science, 272, 577602.

Moore, G.W. 1994. Terranes and the tectonic assembly of South America: the fifth circum-Pacific terrane conference. Journal of South American Earth Sciences, 7 (3-4), 235-239.

Mortimer, N. 2004. New Zealand's geological foundations. Gondwana Research, 7 (1), 261-272.

Mortimer, N. \& CoOper, A.F. 2004. U-Pb and Sm-Nd ages from the Alpine Schist, New Zealand. New Zealand Journal of Geology and Geophysics, 47 (1), 2128.

Mortimer, N. \& PARKInSON, D. 1996. Hikurangi Plateau: a Cretaceous large igneous province in the southwest Pacific Ocean. Journal of Geophysical Research, 101 (B1), 687-696.

Mortimer, N., Tulloch, A.J., Spark, R.N., WAlKer, N.W., Ladley, E., Allibone, A. \& Kimbrough, D.L. 1999. Overview of the Median batholith, New Zealand: a new interpretation of the geology of the Median Tectonic Zone and adjacent rocks. Journal of African Earth Sciences, 29 (1), 257-268.

MPODOZIS, C. \& FORSYTHE, R. 1983. Stratigraphy and geochemistry of accreted fragments of the ancestral Pacific floor in southern South America. Palaeogeography Palaeoclimatology Palaeoecology, 41 (1-2), 103-124.

Muir, R.J., IRELAND, T.R., WeAver, S.D., BradshaW, J.D., Evans, J.A., EBy, G.N. \& SHELLEY, D. 1998. Geochronology and geochemistry of a Mesozoic magmatic arc system, Fiordland, New Zealand. Journal of the Geological Society, London, 155 (6), 1037-1052.

MurPhy, J.B. \& KePPIE, J.D. 2003. Collisional orogenesis in the geological record and modern analogues. Tectonophysics, 365 (1-4), 1-5.

MuRPHY, J.B. \& NANCE, R.D. 2003. Do supercontinents introvert or extrovert?: SmNd isotope evidence. Geology, 31 (10), 873-876.

Murray, C.G., Fergusson, C.L., Flood, P.G., Whitaker, W.G. \& Korsch, R.J. 1987. Plate tectonic model for the Carboniferous evolution of the New England fold belt. Australian Journal of Earth Sciences, 34 (2), 213-236.

NANCE, R.D., MurPhy, J.B. \& KePPIE, J.D. 2004. Nick Rast and the recognition of the Avalonian Arc. Journal of Geodynamics, 37 (3-5), 437-455.

NELSON, E., FORSYTHE, R. \& ARIT, I. 1994. Ridge collision tectonics in terrane development. Journal of South American Earth Sciences, 7 (3-4), 271-278.

NichOLS, G.J. \& CANTRILL, D.J. 2002. Tectonic and climatic controls on a Mesozoic forearc basin succession, Alexander Island, Antarctica. Geological Magazine, 139 (3), 313-330. 
NodA, A., TAKeUCHI, M. \& ADACHI, M. 2004. Provenance of the Murihiku Terrane, New Zealand: evidence from the Jurassic conglomerates and sandstones in Southland. Sedimentary Geology, 164 (3-4), 203-222.

O'Brien, S.J., Wardle, R.J. \& KING, A.F. 1983. The Avalon zone: a Pan-African terrane in the Appalachian orogen of Canada. Geological Journal, 18 (3), 195-222.

O'Sullivan, P.B., Foster, D.A., Kohn, B.P. \& Gleadow, A.J.W. 1996. Multiple postorogenic denudation events: an example from the eastern Lachlan fold belt, Australia. Geology, 24 (6), 563-566.

PANKhurst, R.J., WeAVER, S.D., BradshaW, J.D., StOREy, B.C. \& IrELAND, T.R. 1998. Geochronology and geochemistry of pre-Jurassic superterranes in Marie Byrd Land, Antarctica. Journal of Geophysical Research, 103 (B2), 25292547.

Parfenov, L.M., NoKleberg, W.J. \& KhanchuK, A.I. 2000. Compilation principles and the main units of the legend for the geodynamics map of north and central Asia, Russian southern Far East, Korea and Japan. Geology of the Pacific Ocean, 15, 463-482.

Pavlis, T.L., Picornell, C., Serpa, L., Bruhn, R.L. \& Plafker, G. 2004. Tectonic processes during oblique collision: insights from the St. Elias orogen, northern North American Cordillera. Tectonics, 23 (3), 1-14, TC3001, 10.1029/2003TC001557.

Pedrosa-Soares, A.C., Noce, C.M., Wiedemann, C.M. \& Pinto, C.P. 2001. The Aracuai-West Congo Orogen in Brazil: an overview of a confined orogen formed during Gondwanaland assembly. Precambrian Research, 110 (1-4), 307-323.

Phillips, W.E.A., Stillman, C.J. \& MurPhy, T. 1976. A Caledonian plate tectonic model. Journal of the Geological Society, London, 132 (3), 579-609.

Pickering, K.T., BAssetT, M.G. \& SiVETER, D.J. 1988. Late Ordovician-early Silurian destruction of the Iapetus Ocean: Newfoundland, British Isles and Scandinavia: a discussion. Transactions of the Royal Society of EdinburghEarth Sciences, 79, 361-382.

Piercey, S.J., Murphy, D.C., Mortensen, J.K. \& Creaser, R.A. 2004. MidPaleozoic initiation of the northern Cordilleran marginal back-arc basin: geologic, geochemical, and neodymium isotope evidence from the oldest mafic magmatic rocks in the Yukon-Tanana terrane, Finlayson Lake district, southeast Yukon, Canada. Geological Society of America Bulletin, 116 (9-10), 1087-1106.

PigRAM, C.J. \& DAVIES, H.L. 1987. Terranes and the accretion history of the New Guinea orogen. Bureau of Mineral Resources Journal of Australian Geology and Geophysics, 10, 193-211.

POlAT, A. \& KerRICH, R. 2001. Geodynamic processes, continental growth, and mantle evolution recorded in late Archean greenstone belts of the southern Superior Province, Canada. Precambrian Research, 112 (1-2), 5-25.

RAESIDE, R.P. \& BARR, S.M. 1990. Geology and tectonic development of the Bras D'Or suspect terrane, Cape Breton Island, Nova Scotia. Canadian Journal of Earth Sciences, 27 (10), 1371-1381.

RAmos, V.A. 1988. Late Proterozoic-Early Paleozoic of South America: a collisional history. Episodes, 11 (3), 168-174. 
Ramos, V.A., Jordan, T.E., Allmendinger, R.W., Mpodozis, C., KaY, S.M., Cortes, J.M. \& PALMA, M. 1986. Paleozoic terranes of the central ArgentineChilean Andes. Tectonics, 5 (6), 855-880.

Rankin, D.W., Furnes, H., Bishop, A.C., CABAnis, B., Milton, D.J., O'Brien, S.J. \& THORPE, R.S. 1988. Plutonism and volcanism related to the pre-Arenig evolution of the Caledonide-Appalachian orogen. In: HARRIS, A.L. \& FETTES, D.J. (eds) The Caledonian-Appalachian Orogen. Geological Society, London, Special Publications, 38, 149-183.

RAPALINI, A.E. 2005. The accretionary history of southern South America from the latest Proterozoic to the Late Paleozoic: some paleomagnetic constraints. In: Vaughan, A.P.M., LEAT, P.T. \& PANKhurst, R.J. (eds) Terrane Processes at the Margins of Gondwana. Geological Society, London, Special Publications, this volume.

Rapela, C.W., Pankhurst, R.J., Fanning, C.M. \& Hervé, F. 2005. Pacific subduction coeval with the Karoo mantle plume: the Early Jurassic subcordilleran belt of northwestern Patagonia. In: VAUGHAN, A.P.M., LEAT, P.T. \& PANKHURST, R.J. (eds) Terrane Processes at the Margins of Gondwana. Geological Society, London, Special Publications, this volume.

READING, A.M. 2005. Investigating the deep structure of terranes and terrane boundaries: insights from earthquake seismic data. In: VAUGHAN, A.P.M., LEAT, P.T. \& PANKHURST, R.J. (eds) Terrane Processes at the Margins of Gondwana. Geological Society, London, Special Publications, this volume.

Reading, A.M., KenNetT, B.L.N. \& Dentith, M.C. 2003. Seismic structure of the Yilgarn Craton, Western Australia. Australian Journal of Earth Sciences, 50 (3), 427-438.

RestrePOPACE, P.A. 1992. Petrotectonic characterization of the central Andean terrane, colombia. Journal of South American Earth Sciences, 5 (1), 97-116.

RICHARDS, J.P. \& KerRICH, R. 1993. The Porgera gold mine, Papua New Guinea: magmatic hydrothermal to epithermal evolution of an alkalic-type preciousmetal deposit. Economic Geology, 88 (5), 1017-1052.

Richards, M.A., Jones, D.L., DunCAN, R.A. \& DePaOlO, D.J. 1991. A mantle plume initiation model for the Wrangellia flood basalt and other oceanic plateaus. Science, 254 (5029), 263-267.

RoBerTS, D. 2003. The Scandinavian Caledonides: event chronology, palaeogeographic settings and likely, modern analogues. Tectonophysics, $\mathbf{3 6 5}$ (1-4), 283-299.

Robertson, A.H.F. \& UstaOMer, T. 2004. Tectonic evolution of the intra-pontide suture zone in the Armutlu Peninsula, NW turkey. Tectonophysics, 381 (1-4), 175-209.

Rubin, C.M. \& SALEEBY, J.B. 1991. The Gravina sequence: remnants of a MidMesozoic oceanic arc in southern Southeast Alaska. Journal of Geophysical Research, 96 (B9), 14551-14568.

RYAN, P.D. \& DEWEY, J.F. 1997. Continental eclogites and the Wilson Cycle. Journal of the Geological Society, London, 154 (3), 437-442.

RYAN, R.J. \& SMITH, P.K. 1998. A review of the mesothermal gold deposits of the Meguma Group, Nova Scotia, Canada. Ore Geology Reviews, 13 (1-5), 153183.

Samson, S.D., Patchett, P.J., Gehrels, G.E. \& Anderson, R.G. 1990. Nd and Sr isotopic characterization of the Wrangellia terrane and implications for crustal growth of the Canadian Cordillera. Journal of Geology, 98 (5), 749-762. 
SAmson, S.D., Patchett, P.J., McClelland, W.C. \& Gehrels, G.E. 1991. Nd isotopic characterization of metamorphic rocks in the Coast Mountains, Alaskan and Canadian Cordillera: ancient crust bounded by juvenile terranes. Tectonics, 10 (4), 770-780.

Scarrow, J.H., Ayala, C. \& KimBell, G.S. 2002. Insights into orogenesis: getting to the root of a continent-ocean-continent collision, Southern Urals, Russia. Journal of the Geological Society, London, 159 (6), 659-671.

SCHWARTZ, J.J. \& GROMET, L.P. 2004. Provenance of a late Proterozoic-early Cambrian basin, Sierras de Cordoba, Argentina. Precambrian Research, 129 (1-2), 1-21.

ScotT, S.D. 2001. Deep ocean mining. Geoscience Canada, 28 (2), 87-96.

SENGÖR, A.M.C. 1990. Lithotectonic terranes and the plate tectonic theory of orogeny: A critique of the principles of terrane analysis. In: WILEY, T.J., Howell, D.G. \& Wong, F.L. (eds) Terrane Analysis of China and the Pacific Rim. Circum-Pacific Council for Energy and Mineral Resources Earth Science Series, 13, 9-44.

SENGÖR, A.M.C. \& DeWEY, J.F. 1991. Terranology: vice or virtue? In: DEWEY, J.F., GASs, I.G., CurRY, G.B., HARris, N.B.W. \& SENGÖR, A.M.C. (eds) Allochtonous Terranes. Cambridge University Press, Cambridge, 1-21.

SENGÖR, A.M.C. \& NATALIN, B.A. 1996. Turkic-type orogeny and its role in the making of the continental crust. Annual Review of Earth and Planetary Sciences, 24, 263-337.

SENGÖR, A.M.C., NATAlin, B.A. \& Burtman, V.S. 1993. Evolution of the Altaid tectonic collage and Paleozoic crustal growth in Eurasia. Nature, 364 (6435), 299-307.

SENGÖR, A.M.C. \& OKUROGULlARI, A.H. 1991. The role of accretionary wedges in the growth of continents: Asiatic examples from Argand to plate tectonics. Eclogae Geologicae Helvetiae, 84 (3), 535-597.

SHERLOCK, R.L., Roth, T., SPOONER, E.T.C. \& BRAY, C.J. 1999. Origin of the Eskay Creek precious metal-rich volcanogenic massive sulfide deposit: fluid inclusion and stable isotope evidence. Economic Geology, 94 (6), 803-824.

Shervais, J.W., Kimbrough, D.L., Renne, P., Hanan, B.B., Murchey, B., SnOW, C.A., SCHUMAN, M.M.Z. \& BEAmAN, J. 2004. Multi-stage origin of the Coast Range ophiolite, California: implications for the life cycle of supra-subduction zone ophiolites. International Geology Review, 46 (4), 289-315.

SIDDOWAY, C.S., SASS III, L.C. \& EsSER, R.P. 2005. Kinematic history of the Marie Byrd Land terrane, West Antarctica: direct evidence from Cretaceous mafic dykes. In: VAughan, A.P.M., LeAT, P.T. \& PAnkhurst, R.J. (eds) Terrane Processes at the Margins of Gondwana. Geological Society, London, Special Publications, this volume.

Silberling, N.J., NichOls, K.M., Bradshaw, J.D. \& BlOME, C.D. 1988. Limestone and chert in tectonic blocks from the Esk Head subterrane, South Island, New Zealand. Geological Society of America Bulletin, 100 (8), 1213-1223.

Sivell, W.J. \& MCCulloch, M.T. 2000. Reassessment of the origin of the Dun Mountain Ophiolite, New Zealand: Nd-isotopic and geochemical evolution of magma suites. New Zealand Journal of Geology and Geophysics, 43 (2), 133146.

Smith, P.L., TipPeR, H.W. \& HAM, D.M. 2001. Lower Jurassic Amaltheidae (Ammonitina) in North America: paleobiogeography and tectonic implications. Canadian Journal of Earth Sciences, 38 (10), 1439-1449. 
SMITHIES, R.H. 2000. The Archaean tonalite-trondhjemite-granodiorite (TTG) series is not an analogue of Cenozoic adakite. Earth and Planetary Science Letters, 182 (1), 115-125.

SOH, W., NAKAYAMA, K. \& KimURA, T. 1998. Arc-arc collision in the Izu collision zone, central Japan, deduced from the Ashigara Basin and adjacent Tanzawa Mountains. Island Arc, 7 (3), 330-341.

Song, X.Y., Zhou, M.F., CAO, Z.M. \& Robinson, P.T. 2004. Late Permian rifting of the South China Craton caused by the Emeishan mantle plume? Journal of the Geological Society, 161, 773-781.

Spandler, C., Hermann, J., Arculus, R. \& Mavrogenes, J. 2004. Geochemical heterogeneity and element mobility in deeply subducted oceanic crust: insights from high-pressure mafic rocks from New Caledonia. Chemical Geology, 206 (1-2), 21-42.

Stevens, C.H., Davydov, V.I. \& Bradley, D. 1997. Permian Tethyan Fusulinina from the Kenai Peninsula, Alaska. Journal of Paleontology, 71 (6), 985-994.

Stone, P. \& ThOmson, M.R.A. 2005. Archaeocyathan limestone blocks of likely Antarctic origin in Gondwanan tillite from the Falkland Islands. In: VAughan, A.P.M., LeAt, P.T. \& PANKhurst, R.J. (eds) Terrane Processes at the Margins of Gondwana. Geological Society, London. Special Publications, this volume.

STUMP, E. 1995. The Ross Orogen of the Transantarctic Mountains. Cambridge University Press, Cambridge.

StumP, E., White, A.J.R. \& BoRG, S.G. 1986. Reconstruction of Australia and Antarctica: evidence from granites and recent mapping. Earth and Planetary Science Letters, 79 (3-4), 348-360.

SUTHERLAND, R. 1999. Basement geology and tectonic development of the greater New Zealand region: an interpretation from regional magnetic data. Tectonophysics, 308 (3), 341-362.

Suyehiro, K., TAKahashi, N., Arite, Y., Yokoi, Y., Hino, R., ShinOHARA, M., Kanazawa, T., Hirata, N., TOKuYama, H. \& TAiRA, A. 1996. Continental crust, crustal underplating, and low-Q upper mantle beneath an oceanic island arc. Science, 272 (5260), 390-392.

TAGAMI, T. \& HASEBE, N. 1999. Cordilleran-type orogeny and episodic growth of continents: insights from the circum-Pacific continental margins. Island Arc, 8 (2), 206-217.

Takemura, A., Aita, Y., Hori, R.S., Higuchi, Y., Sporli, K.B., Campbell, H.J., KODAMA, K. \& SAKAI, T. 2002. Triassic radiolarians from the ocean-floor sequence of the Waipapa terrane at Arrow Rocks, Northland, New Zealand. New Zealand Journal of Geology and Geophysics, 45 (3), 289-296.

TEssensohn, F. \& HenJes-Kunst, F. 2005. Northern Victoria Land terranes, Antarctica: far-travelled or local products. In: VAUGHAN, A.P.M., LEAT, P.T. \& PANKHURST, R.J. (eds) Terrane Processes at the Margins of Gondwana. Geological Society, London, Special Publications, this volume.

Thomas, W.A. \& Astini, R.A. 2003. Ordovician accretion of the Argentine Precordillera terrane to Gondwana: a review. Journal of South American Earth Sciences, 16 (1), 67-79.

Thomas, W.A., Astini, R.A. \& BAyonA, G. 2002. Ordovician collision of the Argentine Precordillera with Gondwana, independent of Laurentian Taconic orogeny. Tectonophysics, 345 (1-4), 131-152. 
Thomas, W.A., Astini, R.A. \& Denison, R.E. 2001. Strontium isotopes, age, and tectonic setting of Cambrian salinas along the rift and transform margins of the Argentine Precordillera and southern Laurentia. Journal of Geology, 109 (2), 231-246.

Thomas, W.A., Astini, R.A., Mueller, P.A., Gehrels, G.E. \& WoOden, J.L. 2004. Transfer of the Argentine Precordillera terrane from Laurentia: constraints from detrital-zircon geochronology. Geology, 32 (11), 965-968.

TROP, J.M., RidGWAY, K.D., MANUSZAK, J.D. \& LAYER, P. 2002. Mesozoic sedimentary basin development on the allochthonous Wrangellia composite terrane, Wrangell Mountains basin, Alaska: a long-term record of terrane migration and arc construction. Geological Society of America Bulletin, 114 (6), 693-717.

TwISs, R.J. \& MoORES, E.M. 1992. Structural Geology. Freeman \& Co, New York. UMHOEFER, P.J. \& DORSEY, R.J. 1997. Translation of terranes: lessons from central Baja California, Mexico. Geology, 25 (11), 1007-1010.

UnRUG, R. 1992. The supercontinent cycle and Gondwanaland assembly: component cratons and the timing of suturing events. Journal of Geodynamics, 16 (4), 215-240.

VAUGHAN, A.P.M. 1995. Circum-Pacific mid-Cretaceous deformation and uplift: a superplume-related event? Geology, 23 (6), 491-494.

VAughan, A.P.M. \& Johnston, J.D. 1992. Structural constraints on closure geometry across the Iapetus Suture in eastern Ireland. Journal of the Geological Society, London, 149 (1), 65-74.

Vaughan, A.P.M., KelLey, S.P. \& StOREY, B.C. 2002. Mid-Cretaceous ductile deformation on the Eastern Palmer Land Shear Zone, Antarctica, and implications for timing of Mesozoic terrane collision. Geological Magazine, 139 (4), 465-471.

VAughan, A.P.M. \& Livermore, R.A. 2005. Episodicity of Mesozoic terrane accretion along the Pacific margin of Gondwana: implications for superplumeplate interactions. In: VAUGHAN, A.P.M., LEAT, P.T. \& PANKHURST, R.J. (eds) Terrane Processes at the Margins of Gondwana. Geological Society, London, Special Publication, this volume.

Vaughan, A.P.M. \& StORey, B.C. 2000. The eastern Palmer Land shear zone: a new terrane accretion model for the Mesozoic development of the Antarctic Peninsula. Journal of the Geological Society, London, 157 (6), 1243-1256.

WANDRES, A.M. \& BRADSHAW, J.D. 2005. New Zealand tectonostratigraphy and implications from conglomeratic rocks for the configuration of the SW Pacific of Gondwana. In: VAughan, A.P.M., LEAT, P.T. \& PANKHURST, R.J. (eds) Terrane Processes at the Margins of Gondwana. Geological Society, London, Special Publications, this volume.

Wandres, A.M., Bradshaw, J.D., Weaver, S., MaAs, R., Ireland, T. \& Eby, N. 2004. Provenance analysis using conglomerate clast lithologies: a case study from the Pahau terrane of New Zealand. Sedimentary Geology, 167 (1-2), 5789.

WANG, K.L., ChunG, S.L., O'ReILly, S.Y., Sun, S.S., ShinJo, R. \& CHEN, C.H. 2004. Geochemical constraints for the genesis of post-collisional magmatism and the geodynamic evolution of the northern Taiwan region. Journal of Petrology, 45 (5), 975-1011. 
WANG, Z.H. \& LU, H.F. $1997 .{ }^{40} \mathrm{Ar} /{ }^{39} \mathrm{Ar}$ geochronology and exhumation of mylonitized metamorphic complex in Changle-Nanao ductile shear zone. Science in China, Series D-Earth Sciences, 40 (6), 641-647.

WEAVER, S.D., BradShAW, J.D. \& LAIRD, M.G. 1984. Geochemistry of Cambrian volcanics of the Bowers Supergroup and implications for the early Paleozoic tectonic evolution of Northern Victoria Land, Antarctica. Earth and Planetary Science Letters, 68 (1), 128-140.

WeBer, B. \& KoHLER, H. 1999. Sm-Nd, Rb-Sr and U-Pb geochronology of a Grenville terrane in southern Mexico: origin and geologic history of the Guichicovi complex. Precambrian Research, 96 (3-4), 245-262.

Wellman, H.W. 1955. New Zealand Quaternary tectonics. Geologisches Rundschau, 43, 248-257.

WiLLAN, R.C.R. 2003. Provenance of Triassic-Cretaceous sandstones in the Antarctic Peninsula: implications for terrane models during Gondwana breakup. Journal of Sedimentary Research, 73 (6), 1062-1077.

WILLIAMS, H. \& HATCHER, R.D. 1982. Suspect terranes and accretionary history of the Appalachian orogen. Geology, 10 (10), 530-536.

Williams, H. \& HATCHER, R.D. 1983. Appalachian suspect terranes. Geological Society of America Memoirs, 158, 33-53.

Willner, A.P., Herve, F., Thomson, S.N. \& MAssonne, H.J. 2004. Converging PT paths of Mesozoic HP-LT metamorphic units (Diego de Almagro Island, Southern Chile): evidence for juxtaposition during late shortening of an active continental margin. Mineralogy and Petrology, 81 (1-2), 43-84.

WiLson, J.T. 1966. Did the Atlantic close and then re-open? Nature, 211, 676-681.

Wilson, R.A., Burden, E.T., Bertrand, R., Asselin, E. \& MCCracken, A.D. 2004. Stratigraphy and tectono-sedimentary evolution of the Late Ordovician to Middle Devonian Gaspe Belt in northern New Brunswick: evidence from the Restigouche area. Canadian Journal of Earth Sciences, 41 (5), 527-551.

XiaO, W., Windley, B.F., Badarch, G., Sun, S., Li, J., Qin, K. \& WANG, Z. 2004. Palaeozoic accretionary and convergent tectonics of the southern Altaids: implications for the growth of Central Asia. Journal of the Geological Society, London, 161 (3), 339-342.

YounG, G.M., LonG, D.G.F., FedO, C.M. \& NesBiTT, H.W. 2001. Paleoproterozoic Huronian basin: product of a Wilson cycle punctuated by glaciations and a meteorite impact. Sedimentary Geology, 141, 233-254.

Yu, J.H., Xu, X.S., O'REILly, S.Y., GRIFFIN, W.L. \& ZhANG, M. 2003. Granulite xenoliths from Cenozoic basalts in SE China provide geochemical fingerprints to distinguish lower crust terranes from the North and South China tectonic blocks. Lithos, 67 (1-2), 77-102.

YuMUL, G.P. 2003. The Cretaceous southeast Bohol ophiolite complex, central Philippines: a highly disaggregated supra-subduction zone ophiolite. Journal of Asian Earth Sciences, 21 (8), 957-965.

ZIEGLER, P.A. 1982. Geological Atlas of Western and Central Europe. Shell International Petroleum Mijnbouw B. V., The Hague.

ZimmermanN, U. 2005. Provenance studies of very low- to low-grade metasedimentary rocks of the Puncoviscana complex, northwest Argentina. In: VAughan, A.P.M., LeAT, P.T. \& PANKhurst, R.J. (eds) Terrane Processes at the Margins of Gondwana. Geological Society, London, Special Publication, this volume. 
ZolnAI, G. 1986. North American aulacogens. Bulletin de la Société Géologique de France, 2 (5), 809-818.

\section{Figure captions}

Figure 1: Time-extended “Terra Australis” orogen (cf. Cawood \& Leitch 2002) or

"Australides" including Permo-Triassic orogenesis of the Gondwanian and Hunter-Bowen events (e.g., Collins 1991; O'Sullivan et al. 1996; Curtis 2001) and Triassic-Jurassic and mid-Cretaceous deformation events (Vaughan 1995; Vaughan \& Livermore 2005) depicted on 200 Ma Pangaea reconstruction of Vaughan \& Livermore (2005).

Figure 2: Geographical areas of terrane studies covered by contributions to this volume. 
Vaughan et al. Figure 1

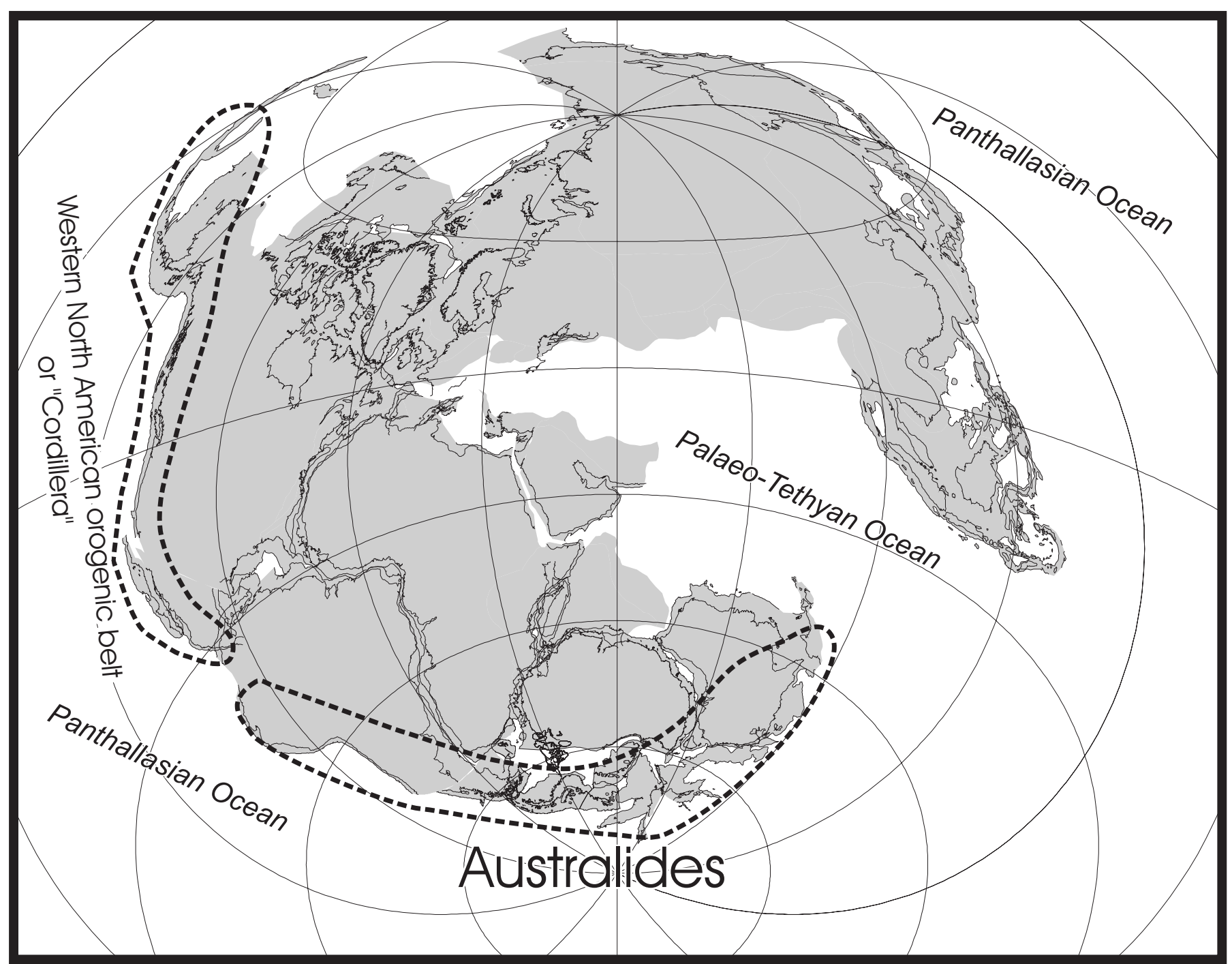


Vaughan et al. Figure 2

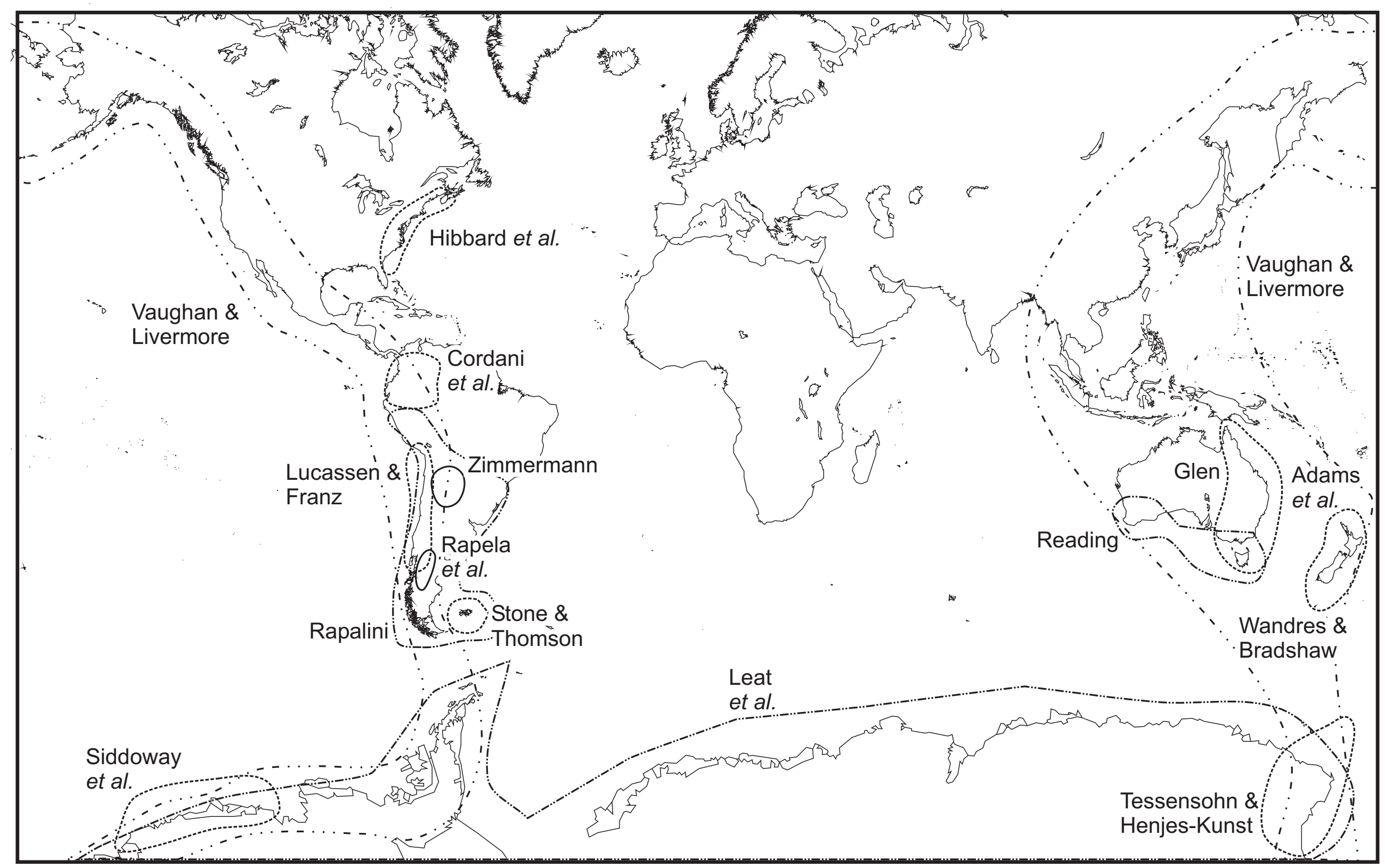

